\title{
Review \\ Evaluation of Microalgae Antiviral Activity and Their Bioactive Compounds
}

\author{
Dora Allegra Carbone ${ }^{1, *,+}$, Paola Pellone ${ }^{2,+}$, Carmine Lubritto ${ }^{1,3}$ and Claudia Ciniglia ${ }^{1}$ (I) \\ 1 Department of Environmental, Biological and Pharmaceutical Sciences and Technologies, University of \\ Campania "Luigi Vanvitelli", Via Vivaldi 43, 81100 Caserta, Italy; carmine.lubritto@unicampania.it (C.L.); \\ claudia.ciniglia@unicampania.it (C.C.) \\ 2 Department of Marine Biotechnology, Stazione Zoologica Anton Dohrn, Villa Comunale, 80121 Naples, Italy; \\ paola.pellone@gmail.com \\ 3 National Institute of Nuclear Physics, Complesso Universitario di Monte S, 80126 Naples, Italy \\ * Correspondence: doraallegracarbone@gmail.com \\ + These authors contributed equally to this work.
}

Citation: Carbone, D.A.; Pellone, P.; Lubritto, C.; Ciniglia, C. Evaluation of Microalgae Antiviral Activity and Their Bioactive Compounds. Antibiotics 2021, 10, 746. https:// doi.org/10.3390/antibiotics10060746

Academic Editor: William N. Setzer

Received: 26 April 2021

Accepted: 14 June 2021

Published: 20 June 2021

Publisher's Note: MDPI stays neutral with regard to jurisdictional claims in published maps and institutional affiliations.

Copyright: () 2021 by the authors. Licensee MDPI, Basel, Switzerland. This article is an open access article distributed under the terms and conditions of the Creative Commons Attribution (CC BY) license (https:// creativecommons.org/licenses/by/ $4.0 /)$.

\begin{abstract}
During the last year, science has been focusing on the research of antivirally active compounds overall after the SARS-CoV-2 pandemic, which caused a great amount of deaths and the downfall of the economy in 2020. Photosynthetic organisms such as microalgae are known to be a reservoir of bioactive secondary metabolites; this feature, coupled with the possibility of achieving very high biomass levels without excessive energetic expenses, make microalgae worthy of attention in the search for new molecules with antiviral effects. In this work, the antiviral effects of microalgae against some common human or animal viruses were considered, focusing our attention on some possible effects against SARS-CoV-2. We summed up the data from the literature on microalgae antiviral compounds, from the most common ones, such as lectins, polysaccharides and photosynthetic pigments, to the less known ones, such as unidentified proteins. We have discussed the effects of a microalgae-based genetic engineering approach against some viral diseases. We have illustrated the potential antiviral benefits of a diet enriched in microalgae.
\end{abstract}

Keywords: microalgae; virus; antiviral compounds; SARS-CoV-2; microalgae antiviral activity; coronavirus disease

\section{Introduction}

Viruses are the smallest and the most common entities on Earth. Their uniqueness lies in the fact that they are able to multiply only inside the cells of other living things. Viruses are generally considered non-living, since they are made up of a core of genetic material, either DNA or RNA, surrounded by a protective protein coat called a capsid [1].

Viruses have had evolutionary success for four main reasons: a massive genetic variation, a variety in means of transmission, a good mechanism to replicate in the host and the ability to survive in the host [2] A viral infection is generally divided into three steps [3]: (i) the virus binds to cell receptors on the cell membrane, transferring its genome into the cytoplasm - this process allows the virus to integrate into the host's genome; (ii) the cells are forced to reproduce the virus genome; (iii) the protein and virion progeny are produced.

Viruses cause several human infections [4]; the so-called severe acute respiratory syndrome is caused by a coronavirus (SARS-CoV). One of these infections has recently dramatically risen to prominence because of its level of lethality along with the high degree of contagiousness of its etiological agent: severe acute respiratory syndrome corona virus 2 (SARS-CoV-2) $[5,6]$.

SARS-CoV-2 is a spherical, enveloped single-stranded RNA virus of the Coronaviridae family. The coronavirus spike (S) protein binds angiotensin-converting enzyme 2 (ACE2) 
receptors, located on the surfaces of many human cells, allowing virus entry and replication, and consequently the development of the disease [6]. This virus appeared at the end of 2019 in Wuhan (China), spread worldwide, and is now considered a pandemic by the World Health Organization, causing many deaths and indirectly also the downfall of the world economy.

The main weapons to prevent viral diseases are vaccines; for some viruses, such as human immunodeficiency virus (HIV), Zaire ebolavirus (ZEBOV), and Dengue virus (DENV), vaccines are still not available [7,8]. Moreover, some steps of virus replication take place inside the cellular metabolic pathway; therefore, it is not easy to treat the virion. However, viruses have particular targets present only in their structure, on which it is possible to act [2].

Some antiviral compounds have natural origins, and microalgae are among the most interesting candidates for their production. Among marine biomedical compounds, $9 \%$ are isolated from algae $[9,10]$, and some of these products are composed of molecules that are currently impossible to reproduce by chemical synthesis [11-13]. Moreover, microalgae have the ability to achieve very high biomass levels, and consequently high compound products, without excessive energy costs [14-16].

One of the first studies on the antiviral activity of microalgae was carried out by Umezawa et al. [17]: an extract containing acid polysaccharides from Chlorella pyrenoidosa was shown to have an inhibitory effect in mice against vesicular stomatitis virus (VSV). However, the greatest interest in the antiviral compounds within microalgae spread only in the mid-1990s, when some cyanobacteria, such as Nostoc and Spirulina, showed interesting results against HIV, which was considered a plague in the 1980s [17-21].

Recently, the interest in microalgae with antiviral effect has also developed in one of the biggest economic sectors, that of aquaculture and its derivatives [22]. Indeed, water is an excellent vector for the transmission of viruses that often kill or seriously damage some animals [23].

In this review, we analyzed the antiviral effects of microalgae against some common human and animal viruses. Moreover, we examined antiviral compounds produced by microalgae, the effect of genetic engineering in this field, and perspectives on a diet enriched in microalgae. We focused our attention on some possible effects against SARS-CoV-2.

\section{Microalgae Antiviral Compounds}

\subsection{Lectins}

Among the different strategies to fight viruses, one involves the prevention of the entry of the microbes into the cells by blocking their interaction with the cell membrane. The most famous preventive agents are lectins, proteins of a non-immunoglobulin nature capable of binding carbohydrates without altering the structures of specific glycosyl ligands; for this reason, they are called carbohydrate-binding agents (CBAs) [24]. Lectins have internal repeats containing a carbohydrate recognition domain (CRDs) and they are classified via this domain.

The orientation of CRDs determines the affinity of the carbohydrate structure. Therefore, some lectins only interact with high-mannose polysaccharides, some with glycan branches, and others with the galactose core [24]. Lectins interact directly with the highglycan structure of virally enveloped glycoproteins that are added after post-translational modification [25].

Microalgae lectins with antiviral activity all originate from cyanobacteria, and all of them have anti-HIV activity (Table 1; Figure 1). 


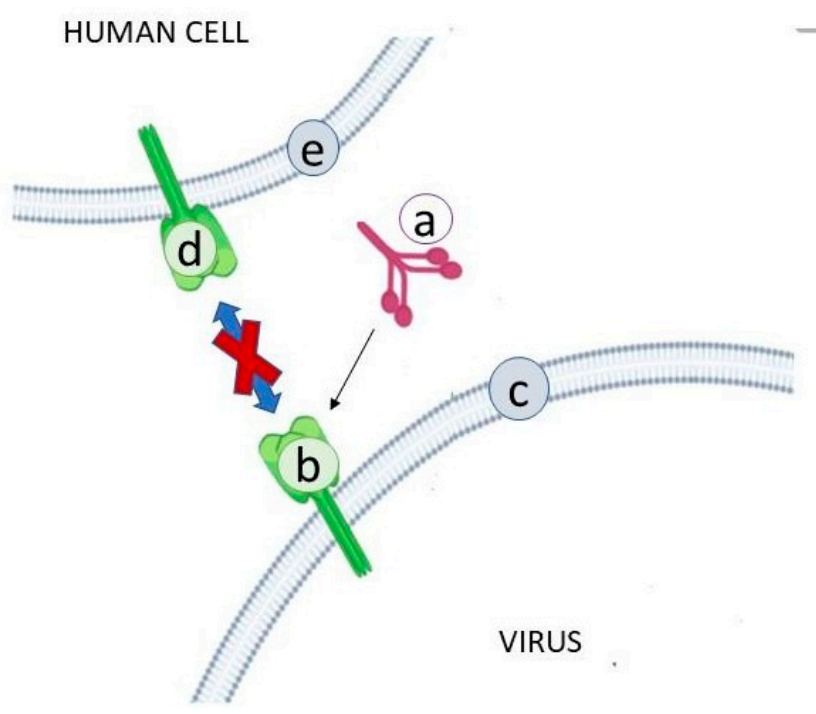

Figure 1. Interaction of the lectin with the virus. The lectin (a) interacts with the high-glycan structure (b) of viral envelope glycoproteins (c), blocking fusion with the glycan structure (d) of human cell membrane glycoproteins (e).

HIV is a positive single-stranded enveloped RNA virus of the genus Lentivirus of the Retroviridae family that infects $\mathrm{CD}^{+}$cells. This virus induces the lowering of $\mathrm{CD}^{+}$ cell levels, making the body more vulnerable to all types of infections and causing acquired immunodeficiency syndrome (AIDS). There are two main types of this virus: HIV1, diffused around the world, and HIV2, diffused only in West Africa because of its low transmissibility $[26,27]$.

In more detail, HIV enters the cells thanks to the envelope protein gp120 that engages the $\mathrm{CD}^{+}$-like receptor and the CCR5- or CXCR4-like coreceptor. After this interaction, the gp120 and gp41 peptides (glycosylated trimeric assemblies interacting with lectins) fuse inside the membrane [28,29] (Figure 1).

There are five lectins from cyanobacteria that are the most studied: Agglutinin OAA, Cyanovirin-N (CV-N), Microcystis Viridis Lectin (MVL), Microvirin, and Scytovirin (Table 1).

Oscillatoria agardhii strain NIES-204 produces a lot of lectins to support blooms on the surfaces of lakes and ponds; among these, there is Agglutinin OAA (molecular weight $13.9 \mathrm{kDa}$ ). This lectin shows anti-HIV1 and anti-HIV 2 activity in vitro, and high mitogenic activity [30-33].

CV-N was extracted from Nostoc ellipsosporum [34,35] and clinical trials around this substance are very advanced: more than 200 papers have been published in the last twenty years [20,36-40]. In the USA, it has become a commercial drug, produced by Cellegy Pharmaceuticals Inc., and in experiments and different clinical trials, it has been used as a rectal and vaginal gel [40].

Different studies have shown that CV-N inhibits the entry into ocular human cells of three viruses: hepatitis C virus (HCV), ZEBOV [41] and herpes virus simplex (HSV) [42,43].

$\mathrm{HCV}$ is an enveloped positive RNA virus from the Flaviviridae family that replicates on intracellular lipid membranes in hepatocytes, but also in peripheral blood mononuclear cells [44].

ZEBOV is a negative-stranded virus from the Filoviridae family causing a hemorrhagic fever with a high mortality rate [45].

HSV is a double-stranded DNA enveloped virus of the Herpesviridae family causing lithic infections in human mucoepithelial cells, such as fibroblasts and epithelial cells. After the infection, the virus moves to sensory nerve axons and causes latent infection in trigeminal ganglia, thanks to some genes that control the latency-associated transcript. Therefore, it can show up again periodically. The two main forms, HSV1 and HSV2, respectively cause oral and genital herpes [46]. 
CV-N also contains anti-influenza A-B viruses (IAV, IBV). They are negative stranded RNA viruses belonging to the Orthomyxo-viridae family. IAV is the only species of the genus Alphainfluenzavirus, and is categorized into subtypes based on the type of each of the two proteins present on the viral envelope, hemagglutinin $(\mathrm{H})$ and neuramidase $(\mathrm{N})$ $(\mathrm{HxNy})$. IBV is the only species of the genus Betainfluenzavirus [47]. Viruses belonging to this family have the ability to adsorb the glycoprotein receptors of the red blood cells, generally causing acute respiratory infections, which are highly contagious. This is called "influenza" in humans and animals [48].

CV-N binds neuraminidase, opening a gap in the cell membrane [49]. Generally, CV-N is expressed in different organisms and carried out different actions, e.g., Escherichia coli, Streptococcus gordonii, Lactobacillus Jensenii [50-54].

Microvirin is an alpha-(1,2)-mannose-specific lectin; it is a protein of $14.7 \mathrm{kDa}$ and shares $33 \%$ amino acid identity with CV-N [33]. It is produced by Microcystis aeruginosa PCC7806 in higher quantities in the presence of iron and light stress conditions [33,55]. Generally, it is expressed thanks to Escherichia coli, and has a good anti-HIV activity, helping to avoid syncytium formation. It has a higher safety profile, but it is not possible to achieve a high productivity level of CV-N [56,57].

MVL is a protein of $13 \mathrm{kDa}$ containing two carbohydrate-binding sites per monomer. It is produced by the PCC7806 strain of Microcystis viridis [58]. As for Agglutinin OAA, data suggest that MVL can be toxic due to its interactions with cellular proteins [56,59,60]. Kachko et al. [43] showed, thanks to biolayer interferometry, that this lectin also has anti-HCV activity, having high affinity with the HCV E1E2 glycoprotein. Scytovirin is produced by Scytonema varium, and it has a weight of $9.71 \mathrm{kDA}$ and a high affinity with tetrammonose. In vitro, its N-terminal residue of the SD1 domain links to HIV1 [61,62]. Western blot analysis confirms that this lectin has some effect against ZEBOV and HCV, too [63]. In more detail, Garrison et al. [45] showed that in some 9,BALB/c mice infected with ZEBOV, the presence of this lectin reduced mortality, and its action had some effects when the lectin was added from the day before the infection until the day after the infection.

Table 1. Microalgae lectins with antiviral effects.

\begin{tabular}{cccc}
\hline \multicolumn{4}{l}{ Lectins Interact Directly with the High-Glycan } \\
\hline Name & Organisture of Viral Envelope & Glycoproteins \\
\hline Agglutinin OAA & Oscillatoria agardhii & HIV1, HIV2 & References \\
\hline CV-N & Nostoc ellipsosporum & $\begin{array}{c}\text { HIV1, HSV1, HCV, } \\
\text { IAV, IBV }\end{array}$ & {$[31-33]$} \\
\hline Microvirin & Microcystis aeruginosa & HIV1, HIV2 & {$[54-42,50,52]$} \\
\hline MVL & Microcystin viridis & HIV1, HIV2, HCV & {$[57-60]$} \\
\hline Scytovirin & Scytonema varium & HIV1, ZEBOV & {$[61-63]$} \\
\hline
\end{tabular}

\subsection{Polysaccharides}

Polysaccharides originate in a great variety of organisms. Among these substances, sulphate polysaccharides and acidic polysaccharides showed the highest antiviral activities.

Sulphate polysaccharides have a high antiviral activity against enveloped viruses. They interact with the positively charged domains of the virus glycoprotein envelope and create a non-reversible complex; as such, they occupy the sites for virus attachment (Figure 2). 


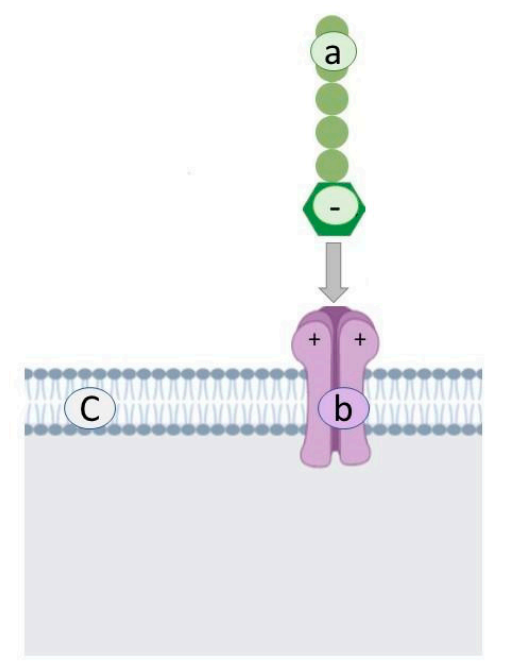

Figure 2. Mechanism of interaction of sulphate polysaccharides. Sulphate polysaccharide (a), thanks to the negative charge of the sulfonate group, interacts with the positively charged domains (b) of the viral glycoprotein envelope (c) and creates a non-reversible complex.

The activity of sulphate polysaccharides is linked to different factors: the degree of sulphation, molecular weight, the distribution of sulphate in the structure and stereochemistry, the effect of counter cations, and hydrophobic and hydrogen bonding interaction [64-68].

Among the different microalgae producing sulphate polysaccharides, the best candidates are definitely Spirulina and Porphyridium (Table 2).

The most famous sulphate polysaccharide from Spirulina is Calcium-spirulan (Ca-SP), which was isolated by Hayashi and Hayashi in 1996 from a hot water extract via cellulose chromatography. Ca-SP showed its activity against HIV1 by interacting with the V3 loop region of the viral envelope, containing gp120, and stopping the syncytium formation between infected cells and non-infected cells $[4,69,70]$. This polysaccharide also prevents syncytium formation in the presence of HSV1 and HSV2 in vitro and in vivo [69].

Lastly, this compound also acts against other enveloped viruses, such as human cytomegalovirus (HCMV), and Mumps virus (MuV), IAV [69].

HCMV is a double-stranded DNA virus of the Herpesviridae family, showing its action against people with compromised immune systems and causing retinitis, pneumonitis, and possible liver failure [71]. MuV is a single-stranded RNA virus of the Paramyxoviridae family causing pain in the salivary glands [71,72].

Mass spectrometry showed that Ca-SP is composed of two types of repeating units of disaccharides (O-rhamnosyl-acofriose and O-hexuronosyl-rhamnose). It has a high antiviral activity against all enveloped viruses thanks to the chelation of calcium ions with a sulphate group $[19,66]$.

Radonic et al. [72] showed that Spirulina platensis also produces TK-V3, another sulphate polysaccharide. In this study, TK-V3 in vitro reduced the replication of two animal viruses, vaccinia virus (VV) and Ectromelia virus (ECTV), but it also has some effect against HSV1. VV is a double-stranded DNA-enveloped virus of the Poxviridae family, and is a constituent of the vaccine that eradicated smallpox and caused smallpox in cattle [71]. ECTV is an enveloped double-stranded DNA virus of the Poxviridae family that causes mousepox in mice [72].

Arthsospira fusiforme produces a sulphate polysaccharide with interesting anti-HSV1 and HSV2 activity, and is thought to be linked to the presence of phycobiliproteins [73].

Porphyridium is a red microalga of the Porphyridiophyceae family that, in recent years, has received great attention for its possible biotechnological uses in the biomedical field. This microalga is encapsulated by an envelope of sulphate polysaccharides with antitumor, antibacterial and antiviral activity [74-78]. 
It has been seen that Porphyridium sp has high activity against murine leukemia virus (MuLV), a single-stranded RNA-enveloped virus from the Retroviridae family causing cancer in mice [72,79], and it has interesting anti-HSV activity, reducing infection by $50 \%$ and showing no cytotoxic effects in vitro [66,71].

Among the different species, Porphyridium cruentum produce some sulphate polysaccharides with high antiviral activity. They have some effects against Varicella zoster $(\mathrm{HH} 3)$, a double-stranded DNA virus of the Herpesvirus family, and VV [71,72]. In a study by Fábregas et al. [80], methanol extracts of this species containing sulphate polysaccharides had high antiviral activity in vitro against two animal viruses, Piscine novirhabdovirus (VHSV) and African swine fever virus (ASFV). VHSV is a single-stranded RNA-enveloped virus from the Rhabdoviridae family causing serious viral hemorrhagic septicemia (VHS) and death in salmonid fishes [80]. ASFV is an enveloped double-stranded DNA virus in the Asfarviridae family with a high mortality rate and causing a hemorrhagic fever, African swine fever (ASF), in domestic pigs [80].

Two dinoflagellates produce some sulphate polysaccharides with antiviral activity: Gyrodinium impudium and Cochlodinium polykrikoides.

Gyrodinium impudium produces a sulphate polysaccharide rich in galactose and glucose called p-KGO3, and this inhibits IAV until six hours after the viral infection. It has some effects on Encephalomyocarditis virus (EMCV) [81], a non-enveloped single-stranded RNA virus of the Piconaviridae family, which is the causative agent of myocarditis and encephalitis, neurological diseases, reproductive disorders and diabetes in many mammalian species [81].

Cochlodinium polykrikoides produces a sulphate polysaccharide composed predominantly of mannose, galactose, glucose and uronic acid, with antiviral effects and no cytotoxicity effect against HIV1, IBV, HSV, MuV and parainfluenza viruses (HPIVs) [82], which are single-stranded viruses of the Paramyxoviridae family causing severe respiratory disease in children under 5 years of age [83].

One type of diatom collected in deep seawater, Navicula directa, produces a sulphate polysaccharide called Naviculan, which is rich in fucose, xylose, galactose, mannose, rhamnose, and has other trace amounts of sugar moieties. It showed its activity in vitro against HSV, IAV and HIV [66].

Lastly, sulphate polysaccharides of green microalga Chlorella autotrophica have shown some antiviral effects against animal viruses such as VHSV and ASFV [80-84].

Not all the polysaccharides of microalgae showing anti-HSV activity are sulphated, but some of them are acid polysaccharides with carboxyl group, phosphate group or ester group.

Nostoflan is one of the most famous acidic polysaccharides. It is extracted from the cyanobacterium Nostoc flagelliforme. It shows a high activity against HSV: in the presence of this substance, there is a reduction in $\mathrm{gD}$, a major component of the virion envelope glycoprotein thought to be required for the fusion of the virus $[85,86]$. Nostoflan also has some effect against IAV in vitro, reducing the virus yield at low concentrations, and in vivo in mice models when injected intranasally [87]. These acid polysaccharides did not show antithrombin activity, a typical collateral effect of some sulphate polysaccharides.

Chlorella pyrenoidosa produced an acid polysaccharide with some effects in mice against vesicular stomatitis virus (VSV) [17-88], a negative stranded enveloped RNA virus of the Rhabdoviridae family causing mucosal vesicles and ulcers in the mouths of cattle, horses and pigs [88]. 
Table 2. Microalgae polysaccharides with antiviral effects.

Polysaccharides Interact with the Positively Charged Domains of the Virus Envelope Glycoprotein and Create a Non-Reversible Complex

Sulphate Polysaccharides:

\begin{tabular}{|c|c|c|c|}
\hline Name & Organism & Virus & References \\
\hline Calcium-spirulan (Ca-SP) & Spirulina & $\begin{array}{l}\text { HIV1, HIV2, HSV1, HSV2, } \\
\text { HCMV, MuV, IAV }\end{array}$ & {$[20,66]$} \\
\hline Naviculan & Navicula directa & HSV, IAV, HIV & \\
\hline TK-V3 & Spirulina platensis & HSV1, ECTV, VV & {$[72]$} \\
\hline / & Arthsospira fusiforme & HSV1, HSV2 & [73] \\
\hline I & Porphyridium sp. & HSV, MuLV, & {$[72,74,75,77-79]$} \\
\hline / & Porphyridium cruentum & HH3, VV, ASFV, VHSV & [80] \\
\hline / & Cochlodinium polykrikoides & HIV1, HSV, IBV, HPIVs, MuV & [81] \\
\hline KGO3 & Gyrodinium impudium & IAV, EMCV, & {$[82,83]$} \\
\hline / & Chlorella autotrophica & VHSV, ASFV & [80] \\
\hline \multicolumn{4}{|l|}{ Acid Polysaccharides } \\
\hline \multirow[t]{2}{*}{ Nostoflan } & Nostoc flagelliforme & HSV, IAV & [84-86] \\
\hline & Chlorella pyrenoidosa & VSV & {$[88]$} \\
\hline
\end{tabular}

\subsection{Pigments}

Microalgae pigments are extensively used in the biomedical field, and several studies show they could be used similarly to antivirals. Among these, the main substances that showed the most interesting results are pheophorbide a, carotenoids, astaxanthin, and phycobiliproteins (allophycocyanin, phycocyanin) (Table 3).

Pheoporbide a (PPba) is formed after the dephytylation and demetallation of chlorophyll a [89]. This substance, known for its antiproliferative activity and used as an anticancer cure [90], shows some antiviral effects, in particular against enveloped viruses [91]. However, its action is not completely clear. It is commonly believed to bind to virus cell receptors, but some studies demonstrate that it also has some effects in post-entry steps [92,93]. In more detail, cyanobacterium Lingbya and green microalga Dunaliella, in particular the species Dunaliella primolecta, are active against HSV1, and inhibit the cytopathic effect of the virus [94]. The presence of pheophorbide as an antiviral compound was confirmed by NMR and MR analysis.

Carotenoids are used in different biotechnology fields, and their antiviral action could be both direct and indirect. It has been seen that extracts of Dunaliella salina directly inhibit the plaque formation of Suid herpesvirus (su-HV1), an enveloped DNA virus of the Herpesviridae family, causing fever and high mortality in piglets [95].

However, it is also known that carotenoids decrease the harmful effects of some viruses indirectly. Indeed, viruses increase the level of reactive oxygen species (ROS) and reactive nitrogen oxygen (RNS), which inhibit virus replication. However, an excessive production of these substances activates transcription nuclear factor-KB (NF-KB), inducing the jak/stat pathway. Consequently, the cytokine is produced at higher levels, and this could cause a fatal attack by the immune system, called a cytokine storm. This hyperinflammation of the cytokine storm is also the origin of two severe syndromes: acute respiratory distress syndrome (ARDS), causing breathlessness and rapid heart rate, and acute lung injury (ALI), involved in the damage of different tissues. One is the consequence of the other: firstly, the alveolar walls are damaged, and consequently, there is a scarcity of oxygen in other organs [96].

Li et al. [97] showed that the beta-carotene of Dunaliella salina inhibits the level of nitric oxide and cytokine; moreover, it downregulates the gene and protein expression of 
the jak/stat pathway in the presence of pseudorabies virus (PRV), an Alphaherpes virus creating neurological problems in mice.

Furthermore, astaxanthin, a xanthophyll produced at high quantities by Hematococcus pluvialis and some diatoms [96], showed antioxidant effects, in particular against the collateral effect of Whispovirus (white spot syndrome virus, WSSV), a double-stranded enveloped DNA virus of the Nimaviridae family that causes white spot disease (WSD), a lethal syndrome in penaeid shrimps, and against infectious hematopoietic necrosis virus (IHNV), a single-stranded DNA virus of the Rhabdoviridae family [54,73,98]

Phycobiliproteins are other substances with antiviral activity.

Spirulina platenis extracts containing allophycocyanin (APC) were able to delay the RNA synthesis in vitro of Enterovirus 71 (EV71), a single-stranded RNA virus of the Piconaviridae family, causing neurological and cardiovascular disorders [99].

A cold-water extract of Spirulina platensis showed anti-IAV activity. Its action is probably linked to the presence of phycocyanin (CPC), which generally downregulates the expression of inflammatory factors caused by viruses [100-102].

Some methanolic extracts of Spirulina or Ankistrodesmus convolotus showed an antiEpstein Barr virus (EBV) effect, inhibiting some proteins, such as LMP1, EBNA and ZEBRA, linked to the lytic cycle of the virus. This activity is probably linked to unidentified pigments of the phycobiliproteins family [103]. EBV is a member of a herpesvirus family that is generally asymptomatic, but, in some cases, it leads to lymphoproliferative disorders, such as Burkitt's lymphoma (BL) and Hodgkin's lymphoma (HL) [104].

Table 3. Microalgae pigments and derivatives with antiviral effects.

\begin{tabular}{|c|c|c|c|c|}
\hline Name & Organism & Virus & Action & References \\
\hline Pheophorbide a & $\begin{array}{c}\text { Dunaliella } \\
\text { Primolecta, Lyngbya }\end{array}$ & HSV1 & $\begin{array}{l}\text { Bonds to virus cell } \\
\text { receptors, effects } \\
\text { post-entry steps }\end{array}$ & [89-91] \\
\hline Carotenoids extracts & Dunaliella salina & $\begin{array}{l}\text { Su-HV1, } \\
\text { PRV }\end{array}$ & $\begin{array}{l}\text { Inhibition of plaque } \\
\text { formation and } \\
\text { downregulation of } \\
\text { gene and protein } \\
\text { expression }\end{array}$ & [94-96] \\
\hline Astaxanthin & Haematococcus pluvialis & $\begin{array}{l}\text { WSSV, } \\
\text { IHNV }\end{array}$ & Antioxidant action & {$[96,98]$} \\
\hline Allophycocyanin & Spirulina platentis & EV71 & $\begin{array}{l}\text { Delay of viral RNA } \\
\text { synthesis in vitro }\end{array}$ & [99] \\
\hline Phycocyanin & Spirulina platentis & IAV & $\begin{array}{l}\text { Downregulation of } \\
\text { expression of } \\
\text { inflammatory factors }\end{array}$ & [102] \\
\hline $\begin{array}{l}\text { Not identified } \\
\text { pigment }\end{array}$ & $\begin{array}{l}\text { Ankistrodesmus } \\
\text { convolotus, } \\
\text { Spirulina }\end{array}$ & EBV & $\begin{array}{c}\text { Inhibition of some } \\
\text { proteins involved in the } \\
\text { lytic cycle }\end{array}$ & {$[103,104]$} \\
\hline
\end{tabular}

2.4. Others Microalgae Compounds with Antiviral Effects

\subsubsection{Peptides and Proteins}

Spirulina maxima produced a peptide called SM that showed antiviral activity against HIV. This peptide inhibits the reverse transcriptase of the virus and p24 antigen production [105].

Other peptides with antiviral activity are cyclic depsipeptides (CDPs), which are particular peptides wherein one or more amino acids are replaced with a hydroxylated carboxylic acid (Table 4).

These peptides are generally synthesized by non-ribosomal peptides in combination with fatty acids in algae, sponges, and other marine organisms [106]. Zainuddin et al. [107,108] 
showed that ichthyopeptin A, a CDP produced by Microcystis ichthyoblabe, had a high IAV activity inhibiting the proteins of the virus cycle.

Different works in the field of aquaculture showed that proteins can also act against viruses.

Studies using HPLC showed that the antiviral effect against nuclear polyhedrosis virus (NPV), a double-stranded DNA-enveloped virus from the Baculoviridae family killing the silkworm Bombyx mori, is linked to the presence of some proteins produced by Spirulina platensis. However, the action is not known [69].

Proteins of Nannochloropsis oculata increase $\alpha$ actin activity and immunity system defense, decreasing the mortality linked to Betanodavirus (or nervous disease virus, NNV), an RNA non-enveloped virus from the Nodaviridae family causing the nerval necrosis of the humpback grouper [109].

\subsubsection{Flavonoids and Polyphenols}

Flavonoids are potent antivirals [110] and some of them are produced by microalgae (Table 4). In different experiments, a methanol extract of the cyanobacterium Geitlerinema sp. strain containing a substance of the flavonoids group showed high anti-HCV activity, reducing the ATPase activity and consequently RNA helicase and virus replication [110-112].

A pigment with a probable polyphenolic nature that shows interesting antiviral activity is marennine [113]. Water-soluble marennine is a blue-grey accessory pigment produced by the tychopelagic diatom Haslea ostrearia during blooms. The pigment's name is derived from the French region Marennes-Olèron, a place rich in this diatom [114-117].

Marennine is produced in high quantities in a photobioreactor in the presence of shear stress [117], and it is utilized for different industrial purposes, such as in food, colorants and cosmetics [114,118]. Olicard et al. [119] showed that it has effective antiviral activity against HSV and HIV; its action is not clear in detail.

\subsubsection{Glycolipids}

Two glycolipids, monogalactosyldiacilglyceride and sulfoquinovosyldiacyglycerol, showed an antiviral effect (Table 4).

Monogalactosyldiacilglyceride is produced by Coccomyxa sp., a green microalga containing more than $30 \%$ lipids by dry weight [120]. This substance is generally the main component of chloroplasts and other organelles. It is a potent viricide of HSV2 in animal cells and in vitro cells. The mechanism of action is not clear: it probably has the ability to change the shape of virus particles, thus harming the viral envelope, and could cause lysis and thus prevent the formation of plaques [121].

Sulfoquinovosyldiacyglycerol is produced by two cyanobacteria, Phormidium sp. and Lyngbya sp. It is a glycolipid that is rich in sulfur, is associated with photosynthetic membranes, and has high antiviral activity, in particular against HIV and HSV [122,123]. This substance inhibits DNA polymerase thanks to the negatively charged side of the sulphonate group in quinovose, a dioxide carbohydrate, which interacts with the positively charged side of the enzyme (Figure 3). 


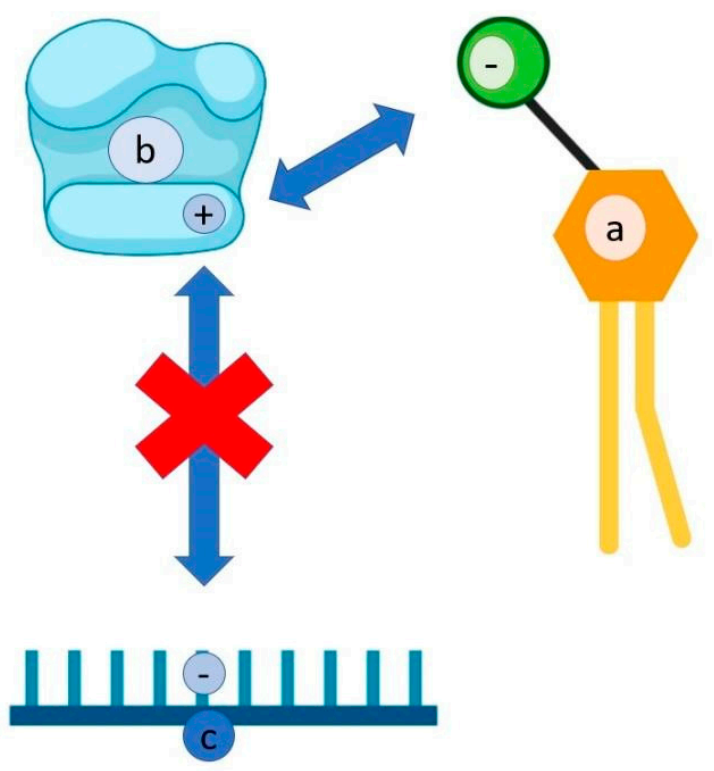

Figure 3. Mechanism of interaction of Sulfoquinovosyldiacyglycerol. Sulfoquinovosyldiacyglycerol, thanks to negative charge (a), interacts with the positive charge of DNA polymerase (b), thus inhibiting the negative charge of the phosphodiester bonds of DNA (c).

Consequently, this enzyme cannot interact with the negative charge of phosphodiester bonds [122-124].

Table 4. Other microalgae compounds with antiviral effects.

\begin{tabular}{|c|c|c|c|c|c|}
\hline Name & Typology & Organism & Virus & Action & References \\
\hline Ichthyopeptin A & Peptide & $\begin{array}{l}\text { Microcystis } \\
\text { ichthyoblabe }\end{array}$ & IAV & $\begin{array}{l}\text { Inhibition of proteins of } \\
\text { virus cycle }\end{array}$ & {$[107,108]$} \\
\hline SM & Peptide & Spirulina maxima & HIV1 & $\begin{array}{l}\text { Inhibition of the } \\
\text { reverse transcriptase of } \\
\text { the virus and p24 } \\
\text { antigen production }\end{array}$ & [105] \\
\hline Not identified protein & protein & $\begin{array}{l}\text { Nannochloropsis } \\
\text { oculata }\end{array}$ & NNV & $\begin{array}{l}\text { Increase in } \alpha \text { actin } \\
\text { activity and immunity } \\
\text { system }\end{array}$ & [109] \\
\hline Not identified protein & protein & $\begin{array}{l}\text { Spirulina } \\
\text { platensis }\end{array}$ & NPV & Decrease in mortality & [105] \\
\hline Not identified flavonoids & flavonoid & Geitlerinema sp. & $\mathrm{HCV}$ & $\begin{array}{l}\text { Reduction in ATPase } \\
\text { activity }\end{array}$ & {$[111,112]$} \\
\hline Marennine & polyphenol & Haslea ostrearia & $\begin{array}{l}\text { HSV, } \\
\text { HIV }\end{array}$ & $\begin{array}{l}\text { Inhibition of virus } \\
\text { invasion and } \\
\text { replication. }\end{array}$ & {$[113-117,119]$} \\
\hline Monogalactosyldiacilglyceride & glycolipid & Coccomixa sp. & HSV2 & $\begin{array}{l}\text { Change of virus shape } \\
\text { causing lysis. }\end{array}$ & [122] \\
\hline Sulfoquinovosyldiacyglycerol & glycolipid & $\begin{array}{l}\text { Phormidium sp. } \\
\text { Lyngbya sp. }\end{array}$ & HIV, HSV & $\begin{array}{l}\text { Inhibition of RNA } \\
\text { polymerase. }\end{array}$ & [123] \\
\hline
\end{tabular}

\section{Antiviral Bioengineering Perspectives Using Microalgae}

Significant assistance in the fight against viruses is offered by the genetic engineering techniques widely used in microalgae, considered as model organisms [125-127] (Table 5).

One of these is the recombinant antibodies technique that allows the production of cloning antibodies in a vector, which are then subsequently expressed in a host. 
Hempel et al. [128,129] used Phaeodactylum tricornutum to treat hepatitis B virus (HBV). In the experiment, monoclonal recombinant human antibody CL.4mAb, which acts against the HBV surface proteins, was expressed and assembled in the endoplasmic reticulum of this microorganism, showing a direct effect against the virus in vitro in human cells.

Genetic engineering is used to create vaccines, which are fundamental weapons against viruses.

The main strategy used to create vaccines, in particular against Sars-CoV 2, is based on a viral vector replicating or not replicating DNA and RNA [130].

An example is the technique of RNA interference (RNAi), wherein a double-stranded RNA interferes with virus mRNAs.

Chlamydomonas reinhardtii, a green microalga, is used as a vector to express doublestranded RNA in yellow head virus (YHV), a single-stranded RNA virus of the Roniviridae family infecting shrimps and prawns. It is given to animals by oral introduction. The organisms treated with these bioengineered microalgae survive the infection of this virus. We have observed that this virus is related to the family of coronaviruses [131].

Other interesting strategies derived from microalgae could be used to create vaccines.

Reddy et al. [132] tried to create a vaccine against infectious bursal disease virus (IBDV), a non-enveloped RNA virus of the Birnaviridae family causing an immunosuppressive disease in poultry $[79,130]$ thanks to the transformation technique. This method allows the introduction of genetic material into a host organism thanks to the support of competence bacteria. The protein VP2 was expressed in Chlorella pyrenoidosa via Agrobacterium tumefaciens; serotype-specific antigenic determinants, located on this protein, induce neutralizing antibodies, and confer protection in young chicken against the action of the virus (Figure 4).

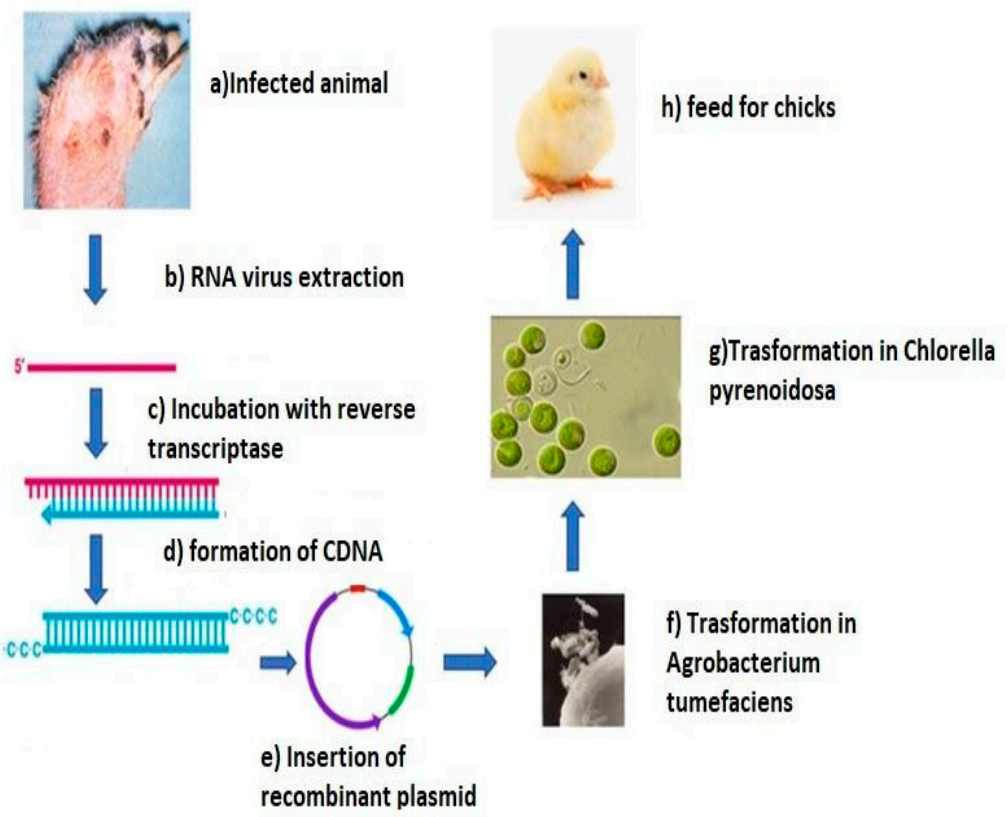

Figure 4. Experiment of Reddy et al. [132].

Màrquez-Escobar et al. [133] tried to create a vaccine against Zika virus (ZIKV), a single-stranded enveloped RNA virus of the Flaviviridae family causing fetal neurodevelopmental defects through microalgae. An antigenic protein of the envelope of ZIKV was expressed in Schizochytrium sp. with the help of Escherichia coli. These modified microalgae were administered orally to mice that then showed a high antiviral response. 
Table 5. Genetic engineering.

\begin{tabular}{llll}
\hline Genetic Engineering & & & \\
\hline Microalgae & Uses & Virus & References \\
\hline $\begin{array}{l}\text { Phaeodactylum } \\
\text { tricornutum }\end{array}$ & $\begin{array}{l}\text { Expression of a } \\
\text { recombinant antibody }\end{array}$ & HBV & {$[128,129]$} \\
\hline $\begin{array}{l}\text { Chlamydomonas } \\
\text { reinhardtii }\end{array}$ & $\begin{array}{l}\text { Expression of RNA } \\
\text { interfering }\end{array}$ & YHV & {$[131]$} \\
\hline Chlorella pyrenoidosa & $\begin{array}{l}\text { Expression of } \\
\text { antigenic protein }\end{array}$ & IBDV & {$[132]$} \\
\hline Schizochytrium sp. & $\begin{array}{l}\text { Expression of } \\
\text { antigenic protein }\end{array}$ & ZIKV & {$[133]$} \\
\hline
\end{tabular}

\section{An Overview of the Antiviral Effects of a Supplementary Microalgae Diet and Its Possible Action on SARS-CoV-2}

The oral introduction of both microalgae and microalgae compounds is widely used to counteract virus diseases as well as cancers. A diet rich in these substances is not invasive and does not have side effects [134].

One of the best candidates for nutritional properties is Spirulina.

A supplementary diet rich in Spirulina could have some antiviral action thanks to its high content of nutraceutical products.

Some of its derivatives are commercially in use as dietary supplements. For example, the company ChromaDex produces an extract called Immulina [135-137], with some action against IAV thanks to its Braun-type lipoproteins. These lipoproteins activate toll-like receptors, and consequently the immunity system [137].

A diet rich in Spirulina is overall known for its beneficial effects against HIV [105,133,138].

Teas et al. [139] noted that there is a difference in the rate of HIV/AIDS incidence among Asia, Chad, and the parts of Africa. This phenomenon was thought to be linked to the consumption of Spirulina, which is very high in Chad and in Asia.

Ngo-Matip et al. [140] showed that a nutrition rich in Spirulina has some effects against the collateral effect of HIV. It increases insulin sensitivity thanks to the antioxidant effects of phycobiliproteins. So, interleukin 6 (IL-6), which inhibits insulin signaling molecules such as insulin receptor substrate, is regularized [141-143], and the activity of the lipoprotein lipase, an important enzyme in the lipid metabolism when it is altered in HIV patients, is increased [144,145].

In a study carried out in Cameroon and Burkina Faso [146], based on a randomized multicenter trial, on undernourished children, it was shown that a diet rich in this microalga increased the production of leukocytes, decreasing the probability of developing AIDS.

In a study by Yakoot and Salem [147], there was a decrease in virulence of HCV and of alanine aminotransferase (ALT) in sixty-six patients with chronic hepatitis after three months of treatment. As in the case of HIV, this effect could be linked to the presence of some compounds, such as fatty acids. Generally, fatty acids increase the immune system cell number, and the effects of a diet rich in these substances against different types of viruses were seen in different studies [148].

A diet rich in fatty acids of Chlorella increases the immunity system of people aged 50-55 after influenza vaccination, and of Salmon trutta caspius after infection with NNV [109].

Therefore, in the case of SARS-CoV-2, a diet rich in fatty acids could have a threefold effect (Figure 5). Firstly, it could increase the amount of $\mathrm{T}$ cells targeting spike proteins of SARS-CoV-2 [149]. Secondly, it could help to disintegrate the viral particle by entering the virus' lipid membrane and destabilizing the bilayer of the envelope; this way, coronavirus' replication in vitro is suppressed $[150,151]$. Thirdly, it could help to prevent collateral effects in vaccinated people (Figure 5). 


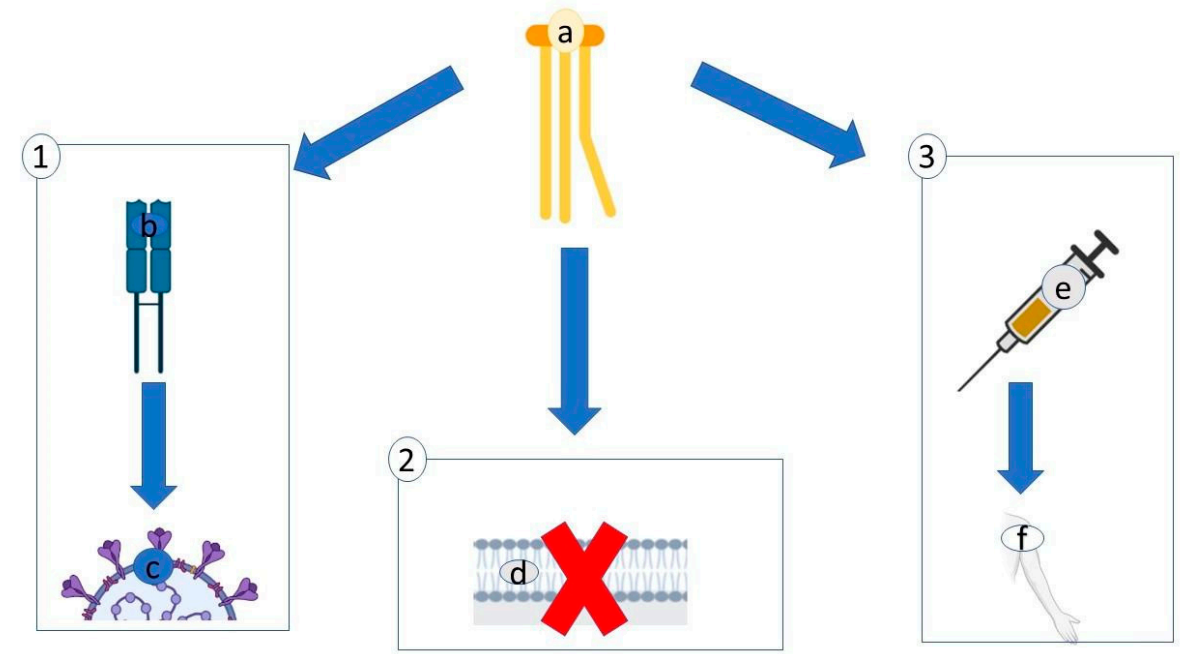

Figure 5. Three potential effects of fatty acids (a) against SARS-CoV-2: (1) FA could increase T cells (b) that target the spike proteins (c); (2) FA penetrates the lipid membrane of the virus, destabilizing the envelope's architecture (d); (3) FA could help to prevent collateral effects in vaccinated people $(\mathbf{e}-\mathbf{f})$.

Moreover, Spirulina and Chlorella are rich in other substances with antioxidant effects, such as vitamins and phenols [152,153].

Hematococcus pluvialis is rich in antioxidant substances, in particular astaxanthin. Choi et al. [154] showed that a nutrition rich in astaxanthin really reduce ALI and ARDS (Figure 6). So, such a diet could be important in preventing the cytokine storm, a collateral effect of SARS-CoV-2 attack, confirmed by the higher presence of IL-6 in SARS-CoV-2 non-survivors [96,99].

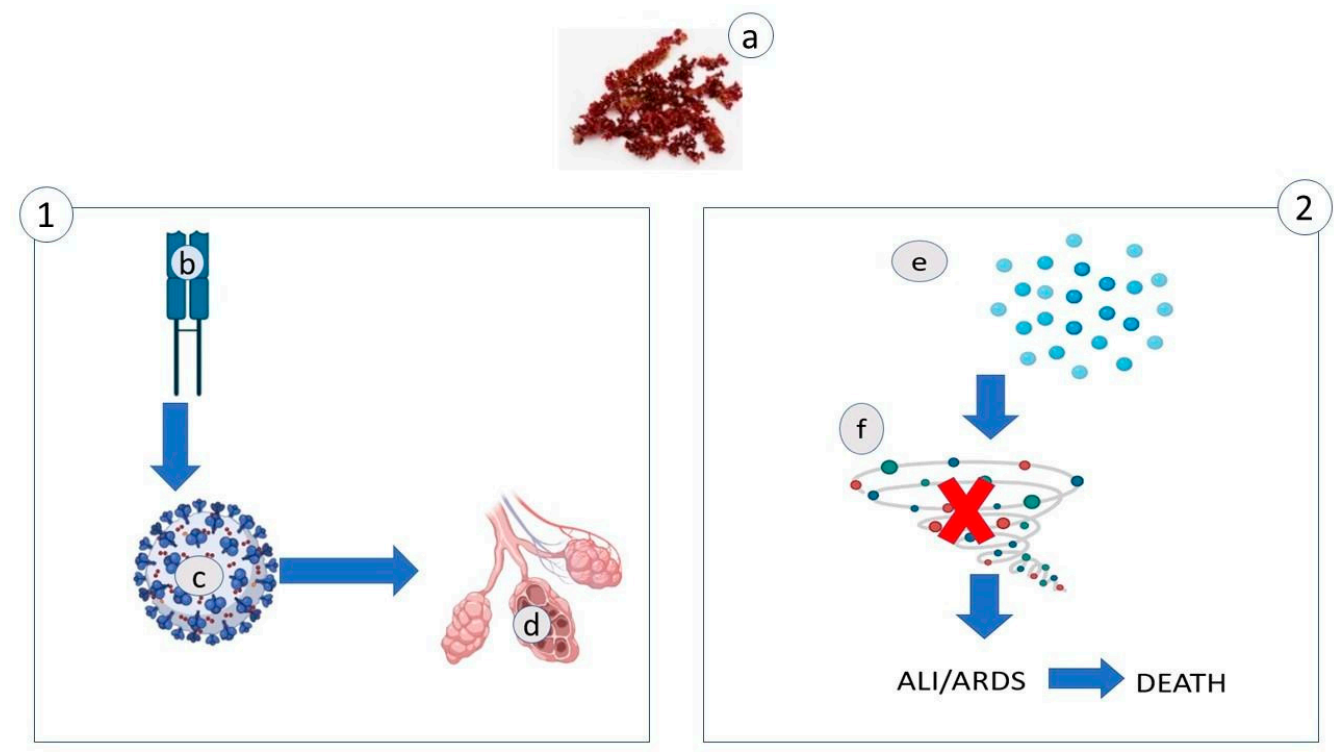

Figure 6. A diet rich in astaxanthin (a) has two possible actions against SARS-CoV-2. First action (1): AST increases the number of lymphocytes (b) in the presence of coronavirus (c) and consequently decreases the oxidative damage of the alveolus (d). Second action (2): AST decreases a specific cytokine (such as IL-6, e), thus preventing cytokine storm (f).

Park et al. [155] showed that a diet supplemented with astaxanthin has an immune booster effect, increasing the number of lymphocytes in peripheral blood cells. This activity could also help to contrast the decrease in lymphocytes and granulocytes in the peripheral blood of people with severe SARS-CoV-2 [96]. 
A diet containing the green microalga Chlamydomonas reinhardtii improves gastrointestinal health thanks to the presence of high-phenol compounds in its biomass [156,157]. So, this kind of diet could also act against another collateral effect of SARS-CoV-2, the gastrointestinal symptoms caused by alterations in the gut microbiome, a symptom reported in $20 \%$ of people affected by this disease [158,159].

Furthermore, a diet rich in polysaccharide-inhibiting viruses that bind to the entry site could help to avoid or weaken a viral attack.

It has been shown that the Carrageenan and Chitosan polysaccharides produced by two different macroalgae have some anti SARS-CoV-2 effects [159-161]. Carrageenan is produced by the macroalga Chondrius crispus, and it is commercially used in a nasal spray solution (Bisolviral ${ }^{\circledR}$ ) to contrast IAV, but also as a food additive (approved by GRAS) [159-161].

Chitosan is produced by Macrocystis Pyrifera, and it is also used as a food additive for cholesterol regulation [159-163].

Immurella, a mix of extracted polysaccharides from Chlorella, had interesting effects when supplemented into the diets of broilers $[48,137,152,164]$.

Reichert [165] showed that the mortality linked to Koi herpes virus (KHV), a doublestranded DNA virus of the Alloherpesviridae family causing a high death rate in koi carps, decreases in the presence of a diet rich in Spirulina platensis exopolysaccharides.

\section{Conclusions}

The SARS-CoV-2 pandemic has demonstrated the necessity of investing in research into new antiviral compounds. Microalgae are considered good candidates to this end. In line with European objectives, they display eco-friendly and eco-sustainable characteristics, produce a high variety of antiviral compounds, and can be used as a supplement in diets without collateral effects. Moreover, these organisms are considered very good candidates for the genetic engineering approach, giving rise to interesting results in recombinant nucleic acid fields that are the basis for new types of vaccines, such as the SARS-CoV2 vaccines.

Author Contributions: D.A.C. proposed the idea and drafted the work and figures, P.P. formed the tables and bibliography, and C.L. and C.C. were the supervisors. All authors have read and agreed to the published version of the manuscript.

Funding: This research received no external funding.

Acknowledgments: We thank C. Brunet and C. Sansone of Anton Dohrn Zoological Station of Naples for their useful suggestions.

Conflicts of Interest: The authors declare that the research was conducted in the absence of any commercial or financial relationships that could be construed as a potential conflict of interest.

\section{References}

1. Jassim, S.A.A.; Naji, M.A. Novel antiviral agents: A medicinal plant perspective. J. Appl. Microbiol. 2003, 95, 412-427. [CrossRef]

2. Wagner, E.K.; Hewlett, M.J. Basic Virology; Blackwell Science: Malden, MA, USA, 2001.

3. Chen, C.H.; Matthews, T.J.; McDanal, C.B.; Bolognesi, D.P.; Greenberg, M.L. A molecular clasp in the human immunodeficiency virus (HIV) type 1 TM protein determines the anti-HIV activity of gp41 derivatives: Implication for viral fusion. J. Virol. 1995, 69, 3771-3775. [CrossRef] [PubMed]

4. De Clercq, E. Current lead natural products for the chemotherapy of human immunodeficiency virus (HIV) infection. Med. Res. Rev. 2000, 20, 323-349. [CrossRef]

5. Drosten, C.; Günther, S.; Preiser, W.; van der Werf, S.; Brodt, H.-R.; Becker, S.; Rabenau, H.; Panning, M.; Kolesnikova, L.; Fouchier, R.A.M.; et al. Identification of a novel coronavirus in patients with Severe acute respiratory syndrome. N. Engl. J. Med. 2003, 348, 1967-1976. [CrossRef] [PubMed]

6. Wu, F.; Zhao, S.; Yu, B.; Chen, Y.M.; Wang, W.; Song, Z.G.; Hu, Y.; Tao, Z.W.; Tian, J.H.; Pei, Y.Y.; et al. A new coronavirus associated with human respiratory disease in China. Nature 2020, 579, 265-269. [CrossRef] [PubMed]

7. Murrell, S.; Wu, S.C.; Butler, M. Review of dengue virus and the development of a vaccine. Biotechnol. Adv. 2011, 29, $239-247$. [CrossRef] 
8. $\quad$ Loutfy, M.R.; Wu, W.; Letchumanan, M.; Bondy, L.; Antoniou, T.; Margolese, S.; Zhang, Y.; Rueda, S.; McGee, F.; Peck, R.; et al. Correction: Systematic review of HIV transmission between heterosexual sero-discordant couples where the HIV-positive partner is fully suppressed on antiretroviral therapy. PLoS ONE 2013, 8, e55747. [CrossRef]

9. Ahmadi, A.; Zorofchian Moghadamtousi, S.; Abubakar, S.; Zandi, K. Antiviral potential of algae polysaccharides isolated from marine sources: A review. BioMed Res. Int. 2015, 30, 1967-1976. [CrossRef]

10. Yasuhara-Bell, J.; Lu, Y. Marine compounds and their antiviral activities. Antivir. Res. 2010, 86, 231-240. [CrossRef] [PubMed]

11. Yamaguchi, K. Recent advances in microalgal bioscience in Japan, with special reference to utilization of biomass and metabolites: A review. J. Appl. Phycol. 1996, 8, 487-502. [CrossRef]

12. Priyadarshani, I.; Rath, B. Commercial and industrial applications of micro algae: A review. Res. Artic. J. Algal Biomass Util. 2012, 2229-6905. [CrossRef]

13. Carbone, D.A.; Olivieri, G.; Pollio, A.; Melkonian, M. Biomass and phycobiliprotein production of Galdieria sulphuraria, immobilized on a twin-layer porous substrate photobioreactor. Appl. Microbiol. Biotechnol. 2020, 104, 3109-3119. [CrossRef] [PubMed]

14. Borowitzka, M.A. Commercial production of microalgae: Ponds, tanks, and fermenters. Prog. Ind. Microbiol. 1999, 35, 313-321. [CrossRef]

15. Pulz, O.; Gross, W. Valuable products from biotechnology of microalgae. Appl. Microbiol. Biotechnol. 2004, 65, 635-648. [CrossRef]

16. Carbone, D.A.; Olivieri, G.; Pollio, A.; Pinto, G.; Melkonian, M. Growth and biomass productivity of Scenedesmus vacuolatus on a twin layer system and a comparison with other types of cultivations. Appl. Microbiol. Biotechnol. 2017, 101, 8321-8329. [CrossRef] [PubMed]

17. Umezawa, I.; Komiyama, K. Acidic polysaccharide CH-1 isolated from Chlorella pyrenoidosa and the use thereof. U.S. Patent 4533548A, 7 August 1985.

18. Reshef, V.; Mizrachi, E.; Maretzki, T.; Silberstein, C.; Loya, S.; Hizi, A.; Carmeli, S. New acylated sulfoglycolipids and digalactolipids and related known glycolipids from cyanobacteria with a potential to inhibit the reverse transcriptase of HIV-1. J. Nat. Prod. 1997, 60, 1251-1260. [CrossRef]

19. Ayehunie, S.; Belay, A.; Baba, T.W.; Ruprecht, R.M. Inhibition of HIV-1 replication by an aqueous extract of Spirulina platensis (Arthrospira platensis). J. Acquir. Immune Defic. Syndr. Hum. Retrovirol. 1998, 18, 7-12. [CrossRef] [PubMed]

20. Hayashi, T.; Hayashi, K.; Maeda, M.; Kojima, I. Calcium Spirulan, an inhibitor of enveloped virus replication, from a blue-green alga Spirulina platensis. J. Nat. Prod. 1996, 59, 83-87. [CrossRef] [PubMed]

21. Huskens, D.; Schols, D. Algal lectins as potential HIV microbicide candidates. Mar. Drugs 2012, 10, 1476-1497. [CrossRef]

22. Muir, J. Managing to harvest? Perspectives on the potential of aquaculture. Philos. Trans. R. Soc. B Biol. Sci. 2005, 360, 191-218. [CrossRef]

23. Bostock, J.; McAndrew, B.; Richards, R.; Jauncey, K.; Telfer, T.; Lorenzen, K.; Little, D.; Ross, L.; Handisyde, N.; Gatward, I.; et al. Aquaculture: Global status and trends. Philos. Trans. R. Soc. B Biol. Sci. 2010, 365, 2897-2912. [CrossRef]

24. Mitchell, C.A.; Ramessar, K.; O'Keefe, B.R. Antiviral lectins: Selective inhibitors of viral entry. Antivir. Res. 2017, 142, 37-54. [CrossRef]

25. Botos, I.; Wlodawer, A. Cyanovirin-N: A sugar-binding antiviral protein with a new twist. Cell. Mol. Life Sci. 2003, 60, 277-287. [CrossRef] [PubMed]

26. Weiss, R.A. How does HIV cause AIDS? Science 1993, 260, 1273-1279. [CrossRef] [PubMed]

27. Douek, D.C.; Roederer, M.; Koup, R.A. Emerging concepts in the immunopathogenesis of AIDS. Annu. Rev. Med. 2009, 60, 471-484. [CrossRef] [PubMed]

28. Leonard, C.K.; Spellman, M.W.; Riddle, L.; Harris, R.J.; Thomas, J.N.; Gregory, T.J. Assignment of intrachain disulfide bonds and characterization of potential glycosylation sites of the type 1 recombinant human immunodeficiency virus envelope glycoprotein (gp120) expressed in Chinese hamster ovary cells. J. Biol. Chem. 1990, 265, 10373-10382. [CrossRef]

29. Kwong, P.D.; Wyatt, R.; Robinson, J.; Sweet, R.W.; Sodroski, J.; Hendrickson, W.A. Structure of an HIV gp 120 envelope glycoprotein in complex with the CD4 receptor and a neutralizing human antibody. Nature 1998, 393, 648-659. [CrossRef]

30. Sato, Y.; Murakami, M.; Miyazawa, K.; Hori, K. Purification and characterization of a novel lectin from a freshwater cyanobacterium, Oscillatoria agardhii. Comp. Biochem. Physiol. B Biochem. Mol. Biol. 2000, 125, 169-177. [CrossRef]

31. Sato, Y.; Okuyama, S.; Hori, K. Primary Structure and Carbohydrate Binding Specificity of a Potent Anti-HIV Lectin isolated from the filamentous cyanobacterium Oscillatoria agardhii. J. Biol. Chem. 2007, 282, 11021-11029. [CrossRef] [PubMed]

32. Sato, T.; Hori, K. Cloning, expression, and characterization of a novel anti-HIV lectin from the cultured cyanobacterium, Oscillatoria agardhii. Fish. Sci. 2009, 75, 743-753. [CrossRef]

33. Kehr, J.C.; Zilliges, Y.; Springer, A.; Disney, M.D.; Ratner, D.D.; Bouchier, C.; Seeberger, P.H.; de Marsac, N.T.; Dittmann, E. A mannan binding lectin is involved in cell-cell attachment in a toxic strain of Microcystis aeruginosa. Mol. Microbiol. 2006, 59, 893-906. [CrossRef] [PubMed]

34. Boyd, M.R.; Gustafson, K.R.; McMahon, J.B.; Shoemaker, R.H.; O'Keefe, B.R.; Mori, T.; Gulakowski, R.J.; Wu, L.; Rivera, M.I.; Laurencot, C.M.; et al. Discovery of cyanovirin-N, a novel human immunodeficiency virus inactivating protein that binds viral surface envelope glycoprotein gp120: Potential applications to microbicide development. Antimicrob. Agents Chemother. 1997, 41, 1521-1530. [CrossRef] 
35. Gustafson, K.R.; Sowder, R.C.; Henderson, L.E.; Cardellina, J.H.; McMahon, J.B.; Rajamani, U.; Pannell, L.K.; Boyd, M.R. Isolation, primary sequence determination, and disulfide bond structure of cyanovirin- $\mathrm{N}$, an anti-HIV (Human immunodeficiency virus) protein from the cyanobacterium Nostoc ellipsosporum. Biochem. Biophys. Res. Commun. 1997, 238, 223-228. [CrossRef] [PubMed]

36. Yang, F.; Bewley, C.A.; Louis, J.M.; Gustafson, K.R.; Boyd, M.R.; Gronenborn, A.M.; Clore, G.M.; Wlodawer, A. Crystal structure of cyanovirin-N, a potent HIV-inactivating protein, shows unexpected domain swapping. J. Mol. Biol. 1999, 288, 403-412. [CrossRef] [PubMed]

37. Barrientos, L.G.; Louis, J.M.; Botos, I.; Mori, T.; Han, Z.; O'Keefe, B.R.; Boyd, M.R.; Wlodawer, A. Reconciliation of X-ray and NMR structures. Structure 2002, 10, 673-686. [CrossRef]

38. Férir, G.; Huskens, D.; Noppen, S.; Koharudin, L.M.I.; Gronenborn, A.M.; Schols, D. Broad anti-HIV activity of the Oscillatoria agardhii agglutinin homologue lectin family. J. Antimicrob. Chemother. 2014, 69, 2746-2758. [CrossRef]

39. Gao, X.; Chen, W.; Guo, C.; Qian, C.; Liu, G.; Ge, F.; Huang, Y.; Kitazato, K.; Wang, Y.; Xiong, S. Soluble cytoplasmic expression, rapid purification, and characterization of cyanovirin-N as a His-SUMO fusion. Appl. Microbiol. Biotechnol. 2010, 85, 1051-1060. [CrossRef]

40. Agarwal, R.; Trivedi, J.; Mitra, D. High yield production of recombinant cyanovirin-N (antiviral lectin) exhibiting significant anti-HIV activity, from a rationally selected Escherichia coli strain. Process Biochem. 2020, 93, 1-11. [CrossRef]

41. Barrientos, L.G.; Gronenborn, A.M. The highly specific carbohydrate-binding protein cyanovirin-N: Structure, anti-HIV/Ebola activity and possibilities for therapy. Mini Rev. Med. Chim. 2005, 5, 220-231. [CrossRef]

42. Tiwari, V.; Shukla, S.Y.; Shukla, D. A sugar binding protein cyanovirin-N blocks herpes simplex virus type-1 entry and cell fusion. Antivir. Res. 2009, 84, 67-75. [CrossRef]

43. Kachko, A.; Loesgen, S.; Shahzad-Ul-Hussan, S.; Tan, W.; Zubkova, I.; Takeda, K.; Wells, F.; Rubin, S.; Bewley, C.A.; Major, M.E. Inhibition of Hepatitis C virus by the cyanobacterial protein Microcystis viridis lectin: Mechanistic differences between the high-mannose specific lectins MVL, CV-N, and GNA. Mol. Pharm. 2013, 10, 4590-4602. [CrossRef] [PubMed]

44. Dubuisson, J.; Cosset, F.L. Virology and cell biology of the Hepatitis C virus life cycle. An update. J. Hepatol. 2014, 61, S3-S13. [CrossRef]

45. Garrison, A.R.; Giomarelli, B.G.; Lear-Rooney, C.M.; Saucedo, C.J.; Yellayi, S.; Krumpe, L.R.H.; Rose, M.; Paragas, J.; Bray, M.; Olinger, G.G.; et al. The cyanobacterial lectin scytovirin displays potent in vitro and in vivo activity against Zaire Ebola virus. Antivir. Res. 2014, 112, 1-7. [CrossRef]

46. Stumpf, M.P.H.; Laidlaw, Z.; Jansen, V.A.A. Herpes viruses hedge their bets. Proc. Natl. Acad. Sci. USA 2002, 99, 15234-15237. [CrossRef]

47. Thompson, W.W.; Shay, D.K.; Weintraub, E.; Cox, N.; Anderson, L.J.; Fukuda, K. Mortality associated with influenza and respiratory syncytial virus in the United States. J. Am. Med. Assoc. 2003, 289, 179-186. [CrossRef] [PubMed]

48. Perrone, L.A.; Plowden, J.K.; García-Sastre, A.; Katz, J.M.; Tumpey, T.M. H5N1 and 1918 Pandemic influenza virus infection. Results in early and excessive infiltration of macrophages and neutrophils in the lungs of mice. PLoS Pathog. 2008, 4, 1000115. [CrossRef]

49. Zambon, M.C. Epidemiology and pathogenesis of influenza. J. Antimicrob. Chemother. 1999, 44, 3-9. [CrossRef]

50. Giomarelli, B.; Provvedi, R.; Meacci, F.; Maggi, T.; Medaglini, D.; Pozzi, G.; Mori, T.; McMahon, J.B.; Gardella, R.; Boyd, M.R. The microbicide cyanovirin-N expressed on the surface of commensal bacterium Streptococcus gordonii captures HIV-1. AIDS 2002, 16, 1351-1356. [CrossRef]

51. Mori, T.; Barrientos, L.G.; Han, Z.; Gronenborn, A.M.; Turpin, J.A.; Boyd, M.R. Functional homologs of cyanovirin-N amenable to mass production in prokaryotic and eukaryotic hosts. Protein Expr. Purif. 2002, 26, 42-49. [CrossRef]

52. Sexton, A.; Drake, P.M.; Mahmood, N.; Harman, S.J.; Shattock, R.J.; Ma, J.K. Transgenic plant production of cyanovirin-N, an HIV microbicide. FASEB J. 2006, 20, 356-358. [CrossRef] [PubMed]

53. Colleluori, D.M.; Tien, D.; Kang, F.; Pagliei, T.; Kuss, R.; McCormick, T.; Watson, K.; McFadden, K.; Chaiken, I.; Buckheit, R.W.; et al. Expression, purification, and characterization of recombinant cyanovirin-N for vaginal anti-HIV microbicide development. Protein Expr. Purif. 2005, 39, 229-236. [CrossRef] [PubMed]

54. Liu, X.; Lagenaur, L.A.; Simpson, D.A.; Essenmacher, K.P.; Frazier-Parker, C.L.; Liu, Y.; Tsai, D.; Rao, S.S.; Hamer, D.H.; Parks, T.P.; et al. Engineered vaginal lactobacillus strain for mucosal delivery of the human immunodeficiency virus inhibitor cyanovirin-N. Antimicrob. Agents Chemother. 2006, 50, 3250-3259. [CrossRef]

55. Zilliges, Y.; Kehr, J.C.; Mikkat, S.; Bouchier, C.; De Marsac, N.T.; Börner, T.; Dittmann, E. An extracellular glycoprotein is implicated in cell-cell contacts in the toxic cyanobacterium Microcystis aeruginosa PCC 7806. J. Bacteriol. 2008, 190, 2871-2879. [CrossRef]

56. Botos, I.; O'Keefe, B.R.; Shenoy, S.R.; Cartner, L.K.; Ratner, D.M.; Seeberger, P.H.; Boyd, M.R.; Wlodawer, A. Structures of the complexes of a potent anti-HIV protein cyanovirin-N and high mannose oligosaccharides. J. Biol. Chem. 2002, 277, 34336-34342. [CrossRef]

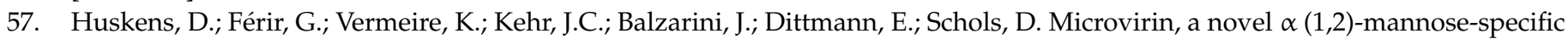
lectin isolated from Microcystis aeruginosa, has anti-HIV-1 activity comparable with that of cyanovirin-N but a much higher safety profile. J. Biol. Chem. 2010, 285, 24845-24854. [CrossRef] [PubMed]

58. Yamaguchi, M.; Ogawa, T.; Muramoto, K.; Kamio, Y.; Jimbo, M.; Kamiya, H. Isolation and characterization of a mannan-binding lectin from the freshwater cyanobacterium (blue-green algae) Microcystis viridis. Biochem. Biophys. Res. Commun. 1999, 265, 703-708. [CrossRef] 
59. Shahzad-ul-Hussan, S.; Gustchina, E.; Ghirlando, R.; Clore, G.M.; Bewley, C.A. Solution structure of the monovalent lectin microvirin in complex with Man $\alpha$ (1-2) Man provides a basis for anti-HIV activity with low toxicity. J. Biol. Chem. 2011, 286, 20788-20796. [CrossRef]

60. Bokesch, H.R.; O'Keefe, B.R.; McKee, T.C.; Pannell, L.K.; Patterson, G.M.L.; Gardella, R.S.; Sowder, R.C.; Turpin, J.; Watson, K.; Buckheit, R.W. A potent novel anti-HIV protein from the cultured cyanobacterium Scytonema varium. Biochemistry 2003, 42 , 2578-2584. [CrossRef] [PubMed]

61. Wood, A. Synthesis of a new scytovirin protein derivative, Sd1-Sd2-Sd2, to decrease Hiv-1 binding affinity. Ph.D. Thesis, University of Mississippi, Oxford, MS, USA, 2013.

62. Takebe, Y.; Saucedo, C.J.; Lund, G.; Uenishi, R.; Hase, S.; Tsuchiura, T.; Kneteman, N.; Ramessar, K.; Tyrrell, D.L.J.; Shirakura, M.; et al. Antiviral lectins from red and blue-green algae show potent in vitro and in vivo activity against Hepatitis C virus. PLoS ONE 2013, 8, e64449. [CrossRef]

63. Breitenbach, L.C.; dos Santos, M.; de Olivieria, W.; de Moura, E. Lectin as antimicrobial agents. J. Appl. Microbiol. 2018, 125, 5. [CrossRef]

64. Neyts, J.; Snoeck, R.; Schols, D.; Balzarini, J.; Esko, J.D.; Van Schepdael, A.; De Clercq, E. Sulfated polymers inhibit the interaction of human cytomegalovirus with cell surface heparan sulfate. Virology 1992, 189, 48-58. [CrossRef]

65. Lüscher-Mattli, M. Polyanions. A lost chance in the fight against HIV and other virus diseases? Antivir. Chem. Chemother. 2000, 11, 249-259. [CrossRef]

66. Lee, J.B.; Srisomporn, P.; Hayashi, K.; Tanaka, T.; Sankawa, U.; Hayashi, T. Effects of structural modification of calcium spirulan, a sulfated polysaccharide from Spirulina Platensis, on antiviral activity. Chem. Pharm. Bull. 2001, 49, 108-110. [CrossRef]

67. Damonte, E.; Matulewicz, M.; Cerezo, A. Sulfated seaweed polysaccharides as antiviral agents. Curr. Med. Chem. 2012, 11, 2399-2419. [CrossRef] [PubMed]

68. Harden, E.A.; Falshaw, R.; Carnachan, S.M.; Kern, E.R.; Prichard, M.N. Virucidal activity of polysaccharide extracts from four algal species against herpes simplex virus. Antivir. Res. 2009, 83, 282-289. [CrossRef] [PubMed]

69. Baba, M.; Schols, D.; Pauwels, R.; Nakashima, H.; De Clercq, E. Sulfated polysaccharides as potent inhibitors of HIV-induced syncytium formation: A new strategy towards AIDS chemotherapy. J. Acquir. Immune Defic. Syndr. 1990, 3, 493-499. [CrossRef] [PubMed]

70. De Clercq, E.; Herdewijn, P. Strategies in the design of antiviral drugs. In Pharmaceutical Sciences Encyclopedia; John Wiley \& Sons, Inc.: Hoboken, NJ, USA, 2010; pp. 1-56.

71. Huleihel, M.; Ishanu, V.; Tal, J.; Arad, S. Antiviral effect of red microalgal polysaccharides on Herpes simplex and Varicella zoster viruses. J. Appl. Phycol. 2001, 13, 127-134. [CrossRef]

72. Radonic, L.M.; Zimmermann, J.M.; Zavallo, D.; López, N.; López Bilbao, M. Rooting in Km selective media as efficient in vitro selection method for sunflower genetic transformation. Electron. J. Biotechnol. 2006, 9, 712-713. [CrossRef]

73. Sharaf, M.; Amara, A.; Aboul-Enein, A.; Helmi, S.; Ballot, A.; Astani, A.; Schnitzler, P. Molecular authentication and characterization of the antiherpetic activity of the cyanobacterium Arthrospira fusiformis. Pharmazie 2010, 65, 132-136. [CrossRef]

74. Malis Arad, S.; Adda, M.; Cohen, E. The potential of production of sulfated polysaccharides from Porphyridium. Plant Soil 1985, 89, 117-127. [CrossRef]

75. Sun, L.; Wang, C.; Shi, Q.; Ma, C. Preparation of different molecular weight polysaccharides from Porphyridium cruentum and their antioxidant activities. Int. J. Biol. Macromol. 2009, 45, 42-47. [CrossRef]

76. Gardeva, E.; Toshkova, R.; Yossifova, L.; Minkova, K.; Gigova, L. Cytotoxic and apoptogenic potential of red microalgal polysaccharides. Biotechnol. Biotechnol. Equip. 2012, 26, 3167-3172. [CrossRef]

77. Kavitha, M.D.; Kathiresan, S.; Bhattacharya, S.; Sarada, R. Culture media optimization of Porphyridium purpureum: Production potential of biomass, total lipids, arachidonic and eicosapentaenoic acid. J. Food Sci. Technol. 2016, 53, 2270-2278. [CrossRef] [PubMed]

78. Gardeva, E.; Toshkova, R.; Minkova, K.; Gigova, L. Cancer protective action of polysaccharide, derived from red microalga porphyridium cruentum: A biological background. Biotechnol. Biotechnol. Equip. 2009, 23, 783-787. [CrossRef]

79. Talyshinsky, M.M.; Souprun, Y.Y.; Huleihel, M.M. Anti-viral activity of red microalgal polysaccharides against retroviruses. Cancer Cell Int. 2002, 2, 8. [CrossRef] [PubMed]

80. Fabregas, J.; García, D.; Fernandez-Alonso, M.; Rocha, A.I.; Gómez-Puertas, P.; Escribano, J.M.; Otero, A.; Coll, J.M. In vitro inhibition of the replication of Haemorrhagic septicaemia virus (VHSV) and African swine fever virus (ASFV) by extracts from marine microalgae. Antivir. Res. 1999, 44, 67-73. [CrossRef]

81. Yim, J.H.; Kim, S.J.; Ahn, S.H.; Lee, C.K.; Rhie, K.T.; Lee, H.K. Antiviral effects of sulfated exopolysaccharide from the marine microalga Gyrodinium impudicum strain KG03. Mar. Biotechnol. 2004, 6, 17-25. [CrossRef] [PubMed]

82. Hasui, M.; Matsuda, M.; Okutani, K.; Shigeta, S. In vitro antiviral activities of sulfated polysaccharides from a marine microalga (Cochlodinium polykrikoides) against human immunodeficiency virus and other enveloped viruses. Int. J. Biol. Macromol. 1995, 17, 293-297. [CrossRef]

83. Schmidt, A.C.; Schaap-Nutt, A.; Bartlett, E.J.; Schomacker, H.; Boonyaratanakornkit, J.; Karron, R.A.; Collins, P.L. Progress in the development of Human parainfluenza virus vaccines. Expert Rev. Respir. Med. 2011, 5, 515-526. [CrossRef]

84. Ligas, M.W.; Johnson, D.C. A herpes simplex virus mutant in which glycoprotein D sequences are replaced by beta-galactosidase sequences binds to but is unable to penetrate into cells. J. Virol. 1988, 62, 1486-1494. [CrossRef] 
85. Kanekiyo, K.; Hayashi, K.; Takenaka, H.; Lee, J.-B.; Hayashi, T. Anti-Herpes simplex virus target of an acidic polysaccharide, nostoflan, from the edible blue-green alga Nostoc flagelliforme. Biol. Pharm. Bull. 2007, 30, 1573-1575. [CrossRef]

86. Hayashi, T. Studies on evaluation of natural products for antiviral effects and their applications. Yakugaku Zasshi 2008, 128, 61-79. [CrossRef] [PubMed]

87. Hayashi, K. A natural sulfated polysaccharide, calcium spirulan, isolated from Spirulina platensis: In vitro and ex vivo evaluation of anti-Herpes simplex virus and anti-Human immunodeficiency virus activities. AIDS Res. Hum. Retrovir. 1996, 12, $1463-1471$. [CrossRef]

88. Plaza, M.; Herrero, H.; Cifuentas, A. Innovative natural functional ingredients from microalgae. J. Agric. 2009, 7159-7170. [CrossRef] [PubMed]

89. Xodo, L.; Rapozzi, V.; Zacchigna, M.; Drioli, S.; Zorzet, S. The chlorophyll catabolite pheophorbide a as a photosensitizer for the photodynamic therapy. Curr. Med. Chem. 2012, 19, 799-807. [CrossRef] [PubMed]

90. Nakamura, Y.; Murakami, A.; Koshimizu, K.; Ohigashi, H. Identification of pheophorbide a and its related compounds as possible anti-tumor promoters in the leaves of Neptunia oleracea. Biosci. Biotechnol. Biochem. 1996, 60, 1028-1030. [CrossRef] [PubMed]

91. Saide, A.; Lauritano, C.; Ianora, A. Pheophorbide a: State of the art. Mar. Drugs 2020, 18, 257. [CrossRef] [PubMed]

92. Bouslama, L.; Hayashi, K.; Lee, J.B.; Ghorbel, A.; Hayashi, T. Potent virucidal effect of pheophorbide a and pyropheophorbide a on enveloped viruses. J. Nat. Med. 2011, 65, 229-233. [CrossRef]

93. Ratnoglik, S.L.; Aoki, C.; Sudarmono, P.; Komoto, M.; Deng, L.; Shoji, I.; Fuchino, H.; Kawahara, N.; Hotta, H. Antiviral activity of extracts from Morinda citrifolia leaves and chlorophyll catabolites, pheophorbide a and pyropheophorbide a, against Hepatitis $C$ virus. Microbiol. Immunol. 2014, 58, 188-194. [CrossRef]

94. Ohta, S.; Ono, F.; Shiomi, Y.; Nakao, T.; Aozasa, O.; Nagate, T.; Kitamura, K.; Yamaguchi, S.; Nishi, M.; Miyata, H. Anti-Herpes simplex virus substances produced by the marine green alga Dunaliella primolecta. J. Appl. Phycol. 1998, 10, 349-356. [CrossRef]

95. Concise Review of Veterinary Virology. Available online: https:/ /www.libyanvet.com/concisereviewofveterinaryvirology.htm (accessed on 19 April 2021).

96. Talukdar, J.; Dasgupta, S.; Nagle, V.; Bhadra, B. COVID-19: Potential of microalgae derived natural astaxanthin as adjunctive supplement in alleviating cytokine storm. SSRN Electron. J. 2020. [CrossRef]

97. Li, W.; Jia, X.; Shen, C.; Zhang, M.; Xu, J.; Shang, Y.; Zhu, K.; Hu, M.; Yan, Q.; Qin, D.; et al. A KSHV microRNA enhances viral latency and induces angiogenesis by targeting GRK2 to activate the CXCR2/AKT pathway. Oncotarget 2016, 7, 32286-32305. [CrossRef]

98. Wang, H.; Dai, A.; Liu, F.; Guan, Y. Effects of dietary astaxanthin on the immune response, resistance to White spot syndrome virus and transcription of antioxidant enzyme genes in Pacific white shrimp Litopenaeus vannamei. Iran. J. Fish. Sci. 2015, 14, 699-718. [CrossRef]

99. Shih, S.-R.; Tsai, K.-N.; Li, Y.-S.; Chueh, C.-C.; Chan, E.-C. Inhibition of Enterovirus 71-induced apoptosis by allophycocyanin isolated from a blue-green alga spirulina platensis. J. Med. Virol. 2003, 70, 119-125. [CrossRef] [PubMed]

100. Geiler, J.; Michaelis, M.; Naczk, P.; Leutz, A.; Langer, K.; Doerr, H.W.; Cinatl, J. N-acetyl-l-cysteine (NAC) inhibits virus replication and expression of pro-inflammatory molecules in A549 cells infected with highly pathogenic H5N1 Influenza A virus. Biochem. Pharmacol. 2010, 79, 413-420. [CrossRef]

101. Chen, X.; Qiao, H.; Liu, T.; Yang, Z.; Xu, L.; Xu, Y.; Ge, H.M.; Tan, R.X.; Li, E. Inhibition of Herpes simplex virus infection by oligomeric stilbenoids through ROS generation. Antivir. Res. 2012, 95, 30-36. [CrossRef]

102. Chen, Y.H.; Chang, G.K.; Kuo, S.M.; Huang, S.Y.; Hu, I.C.; Lo, Y.L.; Shih, S.R. Well-tolerated Spirulina extract inhibits influenza virus replication and reduces virus-induced mortality. Sci. Rep. 2016, 6, 24253. [CrossRef]

103. Kok, Y.Y.; Chu, W.L.; Phang, S.M.; Mohamed, S.M.; Naidu, R.; Lai, P.J.; Ling, S.N.; Mak, J.W.; Lim, P.K.C.; Balraj, P.; et al. Inhibitory activities of microalgal extracts against Epstein-Barr virus DNA release from lymphoblastoid cells. J. Zhejiang Univ. Sci. B 2011, 12, 335-345. [CrossRef]

104. Kok, Y.; Chu, W.; Lai, P.; Tan, B.K.; Ling, S.N.; Shar, M.; Mak, J.W.; Lim, K.C.P.; Rakesh, N.; Pauline, B.; et al. Antiviral activity of microalgae extracts against Epstein-Barr virus in lymphoblastoid cell lines. In Proceedings of the 6th Asia-Pacific Conference on Algal Biotechnology, Makati City, Philippines, 12-15 October 2006.

105. Jang, I.S.; Park, S.J. A Spirulina maxima-derived peptide inhibits HIV-1 infection in a human T cell line MT4. Fish. Aquat. Sci. 2016, 19, 37. [CrossRef]

106. Andavan, G.S.B.; Lemmens-Gruber, R. Cyclodepsipeptides from marine sponges: Natural agents for drug research. Mar. Drugs 2010, 8, 810-834. [CrossRef]

107. Zainuddin, E.N.; Mundt, S.; Wegner, U.; Mentel, R. Cyanobacteria: A potential source of antiviral substances against Influenza virus. Med. Microbiol. Immunol. 2002, 191, 181-182. [CrossRef] [PubMed]

108. Zainuddin, E.N.; Mentel, R.; Wray, V.; Jansen, R.; Nimtz, M.; Lalk, M.; Mundt, S. Cyclic depsipeptides, ichthyopeptins A and B, from Microcystis ichthyoblabe. J. Nat. Prod. 2007, 70, 1084-1088. [CrossRef] [PubMed]

109. Yanuhar, U.; Khumaidi, A. The application of pigment-protein fraction from Nannochloropsis oculata on $\beta$-actin response of Cromileptes altivelis infected with viral nervous necrosis. J. Akuakultur Indones. 2017, 16, 22. [CrossRef]

110. Agrawal, A.D. Pharmacological activities of flavonoids: A review. Int. J. Pharm. Sci. Nanotechnol. 2011, 4, 1394-1398. [CrossRef]

111. Zaenal Mustopa, A.; Umami, R.N.; Putri, P.H.; Susilaningsih, D.; Farida, H. Identification of bioactive compound from microalga BTM 11 as Hepatitis C virus RNA helicase inhibitor. J. Biol. Indones. 2016, 11, 810-834. 
112. Zaenal Mustopa, A.; Ridwan Lembaga Bahasa Lia, M.; Sukmarini, L. Purification and characterization of polysaccharide from microalgae btm 11 as inhibitor of Hepatitis c virus RNA helicase. Indones. J. Pharm. 2015, 49, 108-110. [CrossRef]

113. Daglia, M. Polyphenols as antimicrobial agents. Curr. Opin. Biotechnol. 2012, 23, 174-181. [CrossRef]

114. Mouget, J.L.; Rosa, P.; Vachoux, C.; Tremblin, G. Enhancement of marennine production by blue light in the diatom Haslea ostrearia. J. Appl. Phycol. 2005, 17, 437-445. [CrossRef]

115. Gastineau, R.; Turcotte, F.; Pouvreau, J.-B.; Morançais, M.; Fleurence, J.; Windarto, E.; Prasetiya, F.; Arsad, S.; Jaouen, P.; Babin, M.; et al. Marennine, Promising Blue Pigments from a Widespread Haslea Diatom Species Complex. Mar. Drugs 2014, 12, 3161-3189. [CrossRef]

116. Gastineau, R.; Pouvreau, J.B.; Hellio, C.; Morançais, M.; Fleurence, J.; Gaudin, P.; Bourgougnon, N.; Mouget, J.L. Biological activities of purified marennine, the blue pigment responsible for the greening of oysters. J. Agric. Food Chem. 2012, 60, 3599-3605. [CrossRef]

117. Vandanjon, L. Etude d'un procédé de valorisation d'une microalgue marine: Concentration et purification par techniques à membranes d'un pigment naturel produit par la diatomée Hhaslea ostrearia. Ph.D. Thesis, University of Nantes, Nantes, France, 1997.

118. Chentir, H.; Hamdi, H.; Doumandji, A.; Sadok, H.; Ouada, M. Enhancement of extracellular polymeric substances (EPS) production in Spirulina by two step cultivation process and partial characterization of their polysaccharides moiety. Int. J. Biol. Macromol. 2017, 72, 197-206. [CrossRef]

119. Olicard, C.; Renault, T.; Torhy, C.; Benmansour, A.; Bourgougnon, N. Putative antiviral activity in hemolymph from adult Pacific oysters, Crassostrea gigas. Antivir. Res. 2005, 66, 147-152. [CrossRef] [PubMed]

120. Satoh, A.; Kato, M.; Yamato, K.; Ishibashi, M.; Sekiguchi, H.; Kurano, N.; Miyachi, S. Characterization of the lipid accumulation in a new microalgal species, Pseudochoricystis ellipsoidea (trebouxiophyceae). J. Jpn. Inst. Energy 2010, 89, 909-913. [CrossRef]

121. Inès, M.; Dhouha, G. Glycolipid biosurfactants: Potential related biomedical and biotechnological applications. Carbohydr. Res. 2015, 416, 59-69. [CrossRef]

122. Loya, S.; Reshef, V.; Mizrachi, E.; Silberstein, C.; Rachamim, Y.; Carmeli, S.; Hizi, A. The inhibition of the reverse transcriptase of HIV-1 by the natural sulfoglycolipids from cyanobacteria: Contribution of different moieties to their high potency. J. Nat. Prod. 1998, 61, 891-895. [CrossRef]

123. Matsumoto, K.; Sakai, H.; Takeuchi, R.; Tsuchiya, K.; Ohta, K.; Sugawara, F.; Abe, M.; Sakaguchi, K. Effective form of sulfoquinovosyldiacyglycerol (SQDG) vesicles for DNA polymerase inhibition. Colloids Surf. B Biointerfaces 2005, 46, $175-181$. [CrossRef]

124. Chirasuwan, N.; Chaiklahan, R.; Ruengjitchatchawalya, M.; Bunnag, B.; Tanticharoen, M. Anti HSV-1 Activity of Spirulina platensis polysaccharide. Kasetsart J. Nat. Sci. 2007, 41,311-318.

125. Mayfield, S.; Golden, S.S. Photosynthetic bio-manufacturing:fFood, fuel, and medicine for the 21st century. Photosynth. Res. 2015, 123, 225-226. [CrossRef]

126. Gimpel, J.A.; Henríquez, V.; Mayfield, S.P. In metabolic engineering of eukaryotic microalgae potential and challenges come with great diversity. Front. Microbiol. 2015, 6, 47-56. [CrossRef]

127. Guihéneuf, F.; Khan, A.; Tran, L.S.P. Genetic engineering: A promising tool to engender physiological, biochemical, and molecular stress resilience in green microalgae. Front. Plant Sci. 2016, 7. [CrossRef]

128. Hempel, F.; Maier, U.G. An engineered diatom acting like a plasma cell secreting human IgG antibodies with high efficiency. Microb. Cell Factories 2012, 11, 126. [CrossRef]

129. Hempel, F.; Lau, J.; Klingl, A.; Maier, U.G. Algae as protein factories: Expression of a human antibody and the respective antigen in the diatom Phaeodactylum tricornutum. PLoS ONE 2011, 6. [CrossRef]

130. Khan, M.T.; Islam, M.J.; Parihar, A.; Islam, R.; Jerin, T.J.; Dhote, R.; Ali, M.A.; Laura, F.K.; Halim, M.A. Immunoinformatics and molecular modeling approach to design universal multi-epitope vaccine for SARS-CoV-2. Inform. Med. Unlocked 2021, 24, 100578. [CrossRef]

131. Somchai, P.; Jitrakorn, S.; Thitamadee, S.; Meetam, M.; Saksmerprome, V. Use of microalgae Chlamydomonas reinhardtii for production of double-stranded RNA against Shrimp virus. Aquac. Rep. 2016, 3, 178-183. [CrossRef]

132. Reddy, P.H.; Johnson, A.M.A.; Kumar, J.K.; Naveen, T.; Devi, M.C. Heterologous expression of Infectious bursal disease virus VP2 gene in Chlorella pyrenoidosa as a model system for molecular farming. Plant CellTissue Organ Cult. 2017, 131, 119-126. [CrossRef]

133. Márquez-Escobar, V.A.; Bañuelos-Hernández, B.; Rosales-Mendoza, S. Expression of a Zika virus antigen in microalgae: Towards mucosal vaccine development. J. Biotechnol. 2018, 282, 86-91. [CrossRef]

134. Soni, R.A.; Sudhakar, K.; Rana, R.S. Spirulina from growth to nutritional product: A review. Trends Food Sci. Technol. 2017, 69, 157-171. [CrossRef]

135. Nielsen, C.H.; Balachandran, P.; Christensen, O.; Pugh, N.D.; Tamta, H.; Sufka, K.J.; Wu, X.; Walsted, A.; Schjørring-Thyssen, M.; Enevold, C.; et al. Enhancement of natural killer cell activity in healthy subjects by Immulina ${ }^{\circledR}$, a Spirulina extract enriched for Braun-type lipoproteins. Planta Med. 2010, 76, 1802-1808. [CrossRef]

136. Appel, K.; Munoz, E.; Navarrete, C.; Cruz-Teno, C.; Biller, A.; Thiemann, E. Immunomodulatory and inhibitory effect of Immulina ${ }^{\circledR}$, and Immunloges ${ }^{\circledR}$ in the Ig-E mediated activation of RBL-2H3 Cells. A new role in allergic inflammatory responses. Plants 2018, 7, 13. [CrossRef] 
137. Kefayat, A.; Ghahremani, F.; Safavi, A.; Hajiaghababa, A.; Moshtaghian, J. Spirulina extract enriched for Braun-type lipoprotein (Immulina ${ }^{\circledR}$ ) for inhibition of 4T1 breast tumors' growth and metastasis. Phytother. Res. 2020, 34, 368-378. [CrossRef]

138. Pugh, N.; Ross, S.A.; Eisohly, H.N.; Eisohly, M.A.; Pasco, D.S. Isolation of three high molecular weight polysaccharide preparations with potent immunostimulatory activity from Spirulina platensis, Aphanizomenon flos-aquae and Chlorella pyrenoidosa. Planta Med. 2001, 67, 737-742. [CrossRef]

139. Teas, J.; Hebert, J.R.; Fitton, J.H.; Zimba, P.V. Algae: A poor man's HAART? Med Hypotheses 2004, 62, 507-510. [CrossRef]

140. Ngo-Matip, M.-E.; Pieme, A.; Azabji-Kenfack, M.; Biapa, N.; Germaine, N.; Heike, E.; Moukette Moukette, B.; Emmanuel, K.; Philippe, S.; Mbofung, C.M.; et al. Effects of Spirulina platensis supplementation on lipid profile in HIV-infected antiretroviral naïve patients in Yaounde-Cameroon: A randomized trial study. Lipids Health Dis. 2011, 13, 191. [CrossRef]

141. Riss, J.; Décordé, K.; Sutra, T.; Delage, M.; Baccou, J.C.; Jouy, N.; Brune, J.P.; Oréal, H.; Cristol, J.P.; Rouanet, J.M. Phycobiliprotein C-phycocyanin from Spirulina platensis is powerfully responsible for reducing oxidative stress and NADPH oxidase expression induced by an atherogenic diet in hamsters. J. Agric. Food Chem. 2007, 55, 7962-7967. [CrossRef]

142. Park, H.J.; Lee, Y.J.; Ryu, H.K.; Kim, M.H.; Chung, H.W.; Kim, W.Y. A randomized double-blind, placebo-controlled study to establish the effects of Spirulina in elderly Koreans. Ann. Nutr. Metab. 2008, 52, 322-328. [CrossRef]

143. Siqueira, A.S.; Lima, A.R.J.; de Souza, R.C.; Santos, A.S.; Vianez Júnior, J.L.S.G.; Gonçalves, E.C. In silico analysis of the cyanobacterial lectin scytovirin: New insights into binding properties. Mol. Biol. Rep. 2017, 44, 353-358. [CrossRef]

144. Bhat, V.B.; Madyastha, K.M. Scavenging of peroxynitrite by phycocyanin and phycocyanobilin from Spirulina platensis: Protection against oxidative damage to DNA. Biochem. Biophys. Res. Commun. 2001, 285, 262-266. [CrossRef]

145. Belay, A. The potential application of Spirulina (Arthrospira) as a nutritional and therapeutic supplement in health management. J. Am. Nutraceutical Assoc. 2002, 5, 27-48.

146. Simpore, J.; Zongo, F.; Kabore, F.; Dansou, D.; Bere, A.; Nikiema, J.-B.; Pignatelli, S.; Biondi, D.M.; Ruberto, G.; Musumeci, S. Nutrition rehabilitation of HIV-infected and HIV-negative undernourished children utilizing Spirulina. Ann. Nutr. Metab. 2005, 49, 373-380. [CrossRef]

147. Yakoot, M.; Salem, A. Spirulina platensis versus silymarin in the treatment of chronic Hepatitis C virus infection. A pilot randomized, comparative clinical trial. BMC Gastroenterol. 2012, 12, 32. [CrossRef]

148. Calder, P.C.; Grimble, R.F. Polyunsaturated fatty acids, inflammation and immunity. Eur. J. Clin. Nutr. 2002, 56, 14-19. [CrossRef]

149. Forster, P.; Forster, L.; Renfrew, C.; Forster, M. Phylogenetic network analysis of SARS-CoV-2 genomes. Proc. Natl. Acad. Sci. USA 2020, 117, 9241-9243. [CrossRef]

150. Thormar, H.; Isaacs, C.E.; Brown, H.R.; Barshatzky, M.R.; Pessolano, T. Inactivation of enveloped viruses and killing of cells by fatty acids and monoglycerides. Antimicrob. Agents Chemother. 1987, 31, 27-31. [CrossRef]

151. Subhash, G.V.; Raja, G.; Kumar, K.; Sapre, A.; Dasgupta, S. Possible Prevention of Covid 19 By Usinglinoleic Acid (C18) Rich Algae Oil; AIJR Preprints; 2020; Available online: https://preprints.aijr.org/index.php/ap/preprint/view/36 (accessed on 19 April 2021).

152. Maria De Andrade, L.; De Andrade, C.J.; Dias, M.; Nascimento, C.A.O. Chlorella and Spirulina: Microalgae as sources of functional foods, nutraceuticals, and food supplements; an overview. Food Process. Technol. 2018, 6, 1. [CrossRef]

153. Singh, S.; Kate, B.N.; Banecjee, U.C. Bioactive compounds from cyanobacteria and microalgae: An overview. Crit. Rev. Biotechnol. 2005, 25, 73-95. [CrossRef]

154. Choi, H.D.; Kim, J.H.; Chang, M.J.; Kyu-Youn, Y.; Shin, W.G. Effects of astaxanthin on oxidative stress in overweight and obese adults. Phytother. Res. 2011, 25, 1813-1818. [CrossRef] [PubMed]

155. Park, J.S.; Chyun, J.H.; Kim, Y.K.; Line, L.L.; Chew, B.P. Astaxanthin decreased oxidative stress and inflammation and enhanced immune response in humans. Nutr. Metab. 2010, 7. [CrossRef] [PubMed]

156. Cheung, K.S.; Hung, I.F.; Chan, P.P.; Lung, K.; Tso, E.; Liu, R.; Ng, Y.; Chu, M.Y.; Chung, T.W.; Tam, A.R. Gastrointestinal manifestations of SARS-CoV-2 infection and virus load in fecal samples from the Hong Kong cohort and systematic review and meta-analysis. Gastroenterology 2020, 159, 81-95. [CrossRef]

157. Zuo, T.; Zhang, F.; Lui, G.C.; Yeoh, Y.K.; Li, A.Y.; Zhan, H.; Wan, Y.; Chung, A.; Cheung, C.P.; Chen, N. Alterations in Gut Microbiota of patients with COVID-19 during time of hospitalization. Gastroenterology 2020, 159, 944-955. [CrossRef] [PubMed]

158. Alam, M.A.; Xu, J.L.; Wang, Z. Microalgae Biotechnology for Food, Health and High Values Products; Springer: Singapore, 2020.

159. Fields, F.J.; Lejzerowicz, F.; Schroeder, D.; Ngoi, S.M.; Tran, M.; McDonald, D.; Jiang, L.; Chang, J.T.; Knight, R.; Mayfield, S. Effects of the microalgae Chlamydomonas on gastrointestinal health. J. Funct. Foods 2020, 65, 103738. [CrossRef]

160. Chen, X.; Han, W.; Wang, G.; Zhao, X. Application prospect of polysaccharides in the development of anti-novel coronavirus drugs and vaccines. Int. J. Biol. Macromoules 2020, 164, 331-343. [CrossRef] [PubMed]

161. Pereira, L.; Critchley, A.T. The COVID 19 novel coronavirus pandemic 2020: Seaweeds to the rescue? Why does substantial, supporting research about the antiviral properties of seaweed polysaccharides seem to go unrecognized by the pharmaceutical community in these desperate times? J. Appl. Phycol. 2020, 32, 1875-1877. [CrossRef] [PubMed]

162. Alam, M.A.; Parra-Saldivar, R.; Bilal, M.; Afroze, C.A.; Ahmed, M.N.; Iqbal, H.M.N.; Xu, J. Algae-derived bioactive molecules for the potential treatment of sars-cov-2. Molecules 2021, 26, 2134. [CrossRef] [PubMed]

163. Koide, S.S. Chitin-chitosan: Properties, benefits and risks. Nutr. Res. 1998, 18, 1091-1101. [CrossRef] 
164. Raja, R.; Hemaiswarya, S. Microalgae and immune potential. In Dietary Components and Immune Function; Watson, R.R., Zibadi, S., Preedy, V.R., Eds.; Humana Press, Springer Science + Business Media: New York, NY, USA, 2010; pp. 515-527. [CrossRef]

165. Rechter, S.; König, T.; Auerochs, S.; Thulke, S.; Walter, H.; Dörnenburg, H.; Walter, C.; Marschall, M. Antiviral activity of Arthrospira-derived spirulan-like substances. Antivir. Res. 2006, 72, 197-206. [CrossRef] 